\title{
Geographical variation in head shape of a Neotropical group of toads: the role of physical environment and relatedness
}

\author{
LUCAS N. BANDEIRA $^{1 *}$, JOÃO ALEXANDRINO ${ }^{2}$, CÉLIO F. B. HADDAD ${ }^{1}$ and MARIA \\ TEREZA C. THOMÉ ${ }^{1}$ \\ ${ }^{1}$ Departamento de Zoologia, Instituto de Biociências, Universidade Estadual Paulista 'Julio de \\ Mesquita Filho', Rio Claro São Paulo, 13506-900, Brazil \\ ${ }^{2}$ Departamento de Ciências Biológicas, Universidade Federal de São Paulo, Diadema São Paulo, \\ 09972-270, Brazil
}

Received 28 May 2015; revised 26 April 2016; accepted for publication 29 April 2016

\begin{abstract}
In this study we review the morphological variation within the Rhinella crucifer species group using geometric morphometrics. We sampled 270 specimens from 78 localities comprising all genetic units delimited for the group. We placed 12 landmarks and 89 semi-landmarks defining morphological structures of the anterior region of the body (head and parotoid glands) on standardized photographs of dorsal aspects of specimens. We checked for the existence of size-free morphological variation using exploratory multivariate analyses and tested for differences among categories (genetic units) using canonical variate analyses. We investigated the effects of relatedness by conducting canonical analyses hierarchically, and tested for phylogenetic signal using reconstruction of morphologies on a tree derived from mitochondrial data. We then corrected for relatedness using phylogenetic principal component analysis, and tested for the influence of the physical environment (temperature, humidity and altitude) with a partial Mantel test of matrix correlation. Our results revealed that there is size-free shape variation in the group. Shape changes are related to specific structures in the head, with landmarks and semilandmarks highlighting changes in a complementary way. We were able to statistically detect the effect of phylogenetic distance with landmarks when considering the closest genetic units as a single category. A significant proportion of the variation in head shape can be explained by environmental variables, suggesting that conditions of the physical environment should also be considered as a source of morphological variation.
\end{abstract}

(C) 2016 The Linnean Society of London, Zoological Journal of the Linnean Society, 2016 doi: 10.1111/zoj.12460

ADDITIONAL KEYWORDS: Brazilian Atlantic forest - geometric morphometrics - phylogenetic principal component analysis - phylogenetic signal - Rhinella crucifer group - semi-landmarks.

\section{INTRODUCTION}

The Brazilian Atlantic forest possesses remarkable biodiversity, and the origins of its biota have been the subject of many evolutionary studies in the last decade (Turchetto-Zolet et al., 2013). The number of amphibian species occurring in this biome is outstanding, with over 500 recorded (Haddad et al., 2013). The Rhinella crucifer group of toads is one of the most emblematic components of this anurofauna,

*Corresponding author. E-mail: azebandeira@gmail.com as its species are abundant across the Atlantic forest domain (Baldissera, Caramaschi \& Haddad, 2004). The first species belonging to this group was described by Wied-Neuwied (1821) as Bufo crucifer, but morphological variations among populations attributed to this taxon have been confusing taxonomists over the years, resulting in a list of names and synonyms (Baldissera et al., 2004; Frost, 2014). Many of these forms were described based upon characters with limited or no phylogenetic signal, such as the cross-shaped colour pattern often present on the dorsum and for which the group is named (Baldissera et al., 2004). 
Baldissera et al. (2004) revised the taxonomy of the Rhinella crucifer group on the basis of external morphology and traditional morphometric analyses. In that study the authors made use of a broad sampling effort to delimit five species under the morphological species concept. Three of these species were retained by Baldissera et al. (2004), namely Rhinella crucifer (Wied-Neuwied, 1821), Rhinella ornata (Spix, 1824) and Rhinella henseli (Lutz, 1934). The two remaining species were described as Rhinella abei and Rhinella pombali (Baldissera et al., 2004). For each of these species the authors inferred a nonoverlapping geographical distribution (Baldissera et al., 2004), subsequently further extended by other authors (Lima et al., 2005; Silveira, Salles \& Pontes, 2009). Later, Vaz-Silva, Valdujo \& Pombal (2012) described a sixth species for the group, Rhinella inopina, restricted to Atlantic forest enclaves in the Cerrado biome domain.

In a recent survey, Thomé et al. (2012) combined multilocus sequence data with intensive sampling across the group's distribution to examine the genetic structure in the Rhinella crucifer group. Thomé et al. (2012) employed trees and frequencybased approaches to find five genetic units whose geographical distributions challenged the prevailing taxonomy. Correspondence between genetically distinguishable units and recognized species was straightforward only for $R$. henseli and R. inopina, while for $R$. crucifer and $R$. ornata the species ranges and the distributions of genetic groups overlapped only partially. Rhinella abei appeared nested within $R$. ornata, and $R$. pombali was synonymized to $R$. ornata and $R$. crucifer, as its distribution is largely concordant with a hybrid zone between the latter two species. Additionally, Thomé et al. (2012) suggested the existence of a divergent population pending taxonomic evaluation, recently elevated to species status under the name Rhinella casconi by Roberto, Brito \& Thomé (2014).

One possible explanation for the disparity between genetically and morphologically defined groups in the Rhinella crucifer group is the variation in body size (snout-vent length - SVL) over its geographical distribution. Morphometric multivariate analyses in Baldissera et al. (2004) show that most of the variation in the group is associated with this variable, raising the possibility that size acted as a confounding factor in the morphometric analyses that may otherwise support taxonomic decisions for the group. Furthermore, morphometric studies on anurans have reported variation that covaries with variation in environmental conditions (Castellano \& Giacoma, 1998; Castellano et al., 1999; Rosso, Castellano \& Giacoma, 2004; Schauble, 2004; Kutrup, Bulbul \& Yilmaz, 2006; Marcelino, Haddad
\& Alexandrino, 2009), raising the possibility that local climates might also play a role in generating phenotypic differentiation within the $R$. crucifer group.

In contrast to traditional morphometrics, geometric morphometrics allows for the quantification of pure shape through the definition of homologous landmarks, contours of structures and the use of a statistical formalism that expresses shape change directly as deformation (Bookstein, 1991). Therefore, size-free variation in complex morphological structures is effectively quantified in terms of localized and hierarchical shape phenomena captured at different geometric scales (Bookstein, 1996; Rohlf, Loy \& Corti, 1996; Dryden \& Mardia, 1998). In this study we used geometric morphometrics to reassess morphometric variation in the Rhinella crucifer group and to consider its evolutionary history and local variation relative to environmental conditions (climate and altitude). Our main questions are: (1) Is there size-free shape variation in the group? (2) If so, can this variation be explained by genetic relatedness? (3) Is shape variation influenced by local variation of the physical environment?

\section{MATERIAL AND METHODS}

\section{SAMPLING}

We gathered 270 specimens of the $R$. crucifer group from 78 localities (Fig. 1, Appendix 1). Specimens are deposited in the following institutions: 'Célio Fernando Baptista Haddad' amphibian collection, CFBH (Departamento de Zoologia, Instituto de Biociências IB, Universidade Estadual Paulista - UNESP, Rio Claro, SP, Brazil); herpetological collection of the 'Instituto de Investigación Biológica del Paraguay', IIBPH (Asunción, Paraguay); Museum of Zoology University of São Paulo, MZUSP (Universidade de São Paulo - USP, São Paulo, SP, Brazil); and the Museum of Natural Sciences of the Pontifícia Universidade Católica, MCNPUC-MG (Pontifícia Universidade Católica de Minas Gerais - PUCMG, Belo Horizonte, MG, Brazil). The distributions of body sizes of the different subsets of the sample are illustrated in Figure 2.

According to the results of Thomé et al. (2012), in several cases current taxonomy does not represent evolutionary units in the Rhinella crucifer group and so we assigned each specimen to their respective genetic unit $(\mathrm{G}, \mathrm{N}, \mathrm{P}, \mathrm{C}, \mathrm{c} 1$ and $\mathrm{S}$; Thomé et al., 2012). Assignment was determined genetically, as many of the specimens were used in a previous phylogenetic analysis or originated from the same populations, or, in a few cases, by their geographical origin. Individuals from the transition zone between 


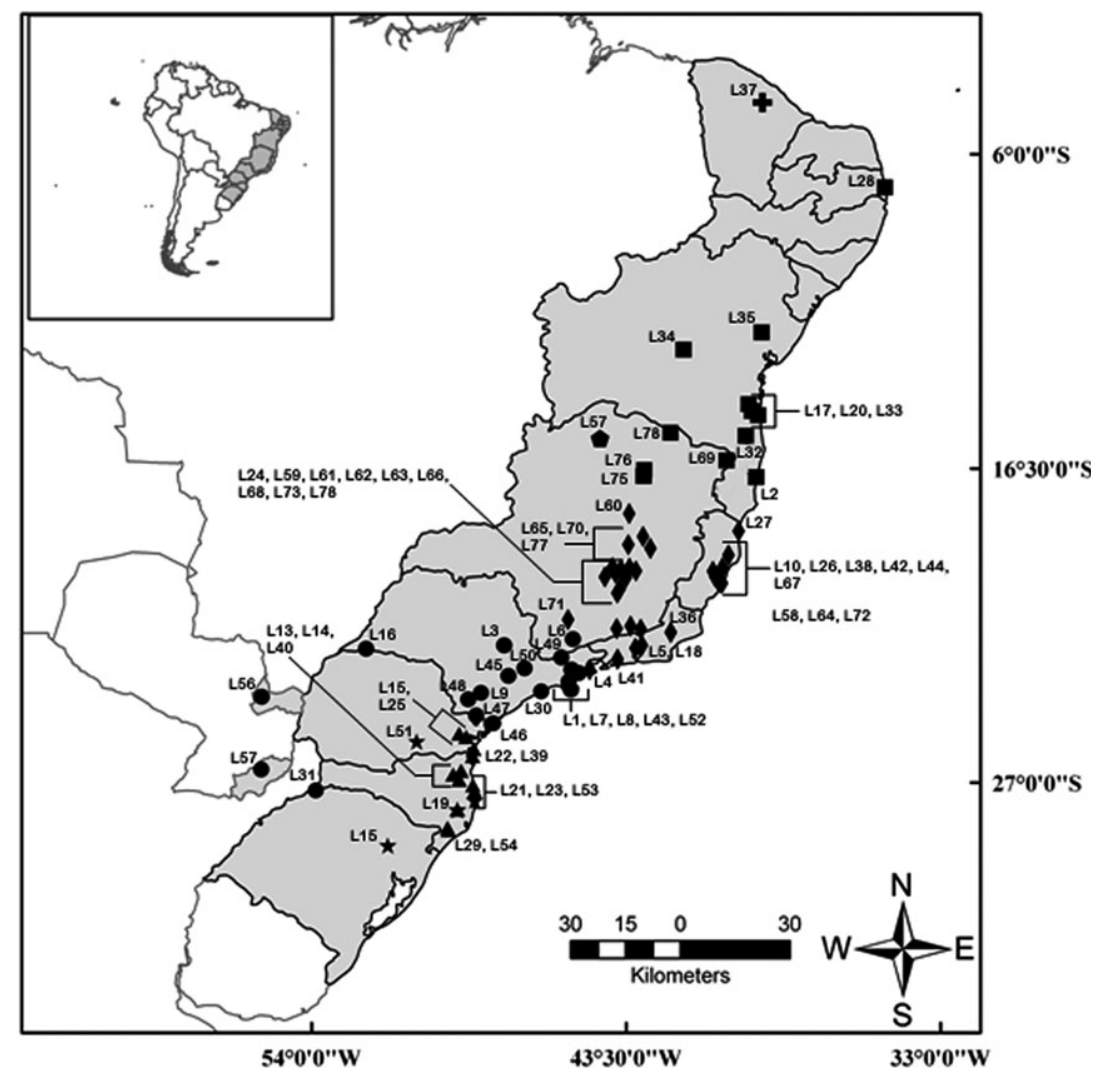

Figure 1. Localities in Brazil and Paraguay sampled in this study. (see Appendix for latitude, longitude and administrative district). Cross, unit G; square, unit N; pentagon, unit P; diamond, unit $\mathrm{H}$; circle, unit $\mathrm{C}$, triangle, unit c1; star, unit S.

A

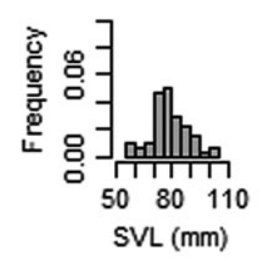

E

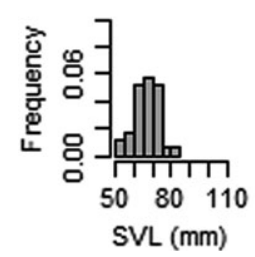

B

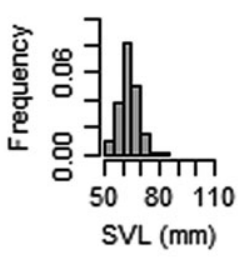

$\mathbf{F}$

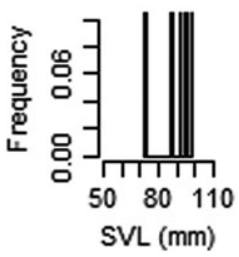

C

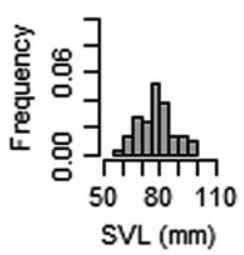

G

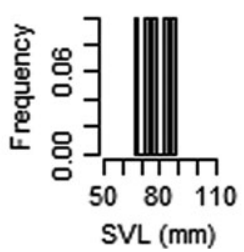

D

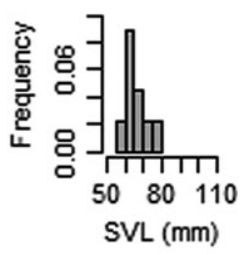

H

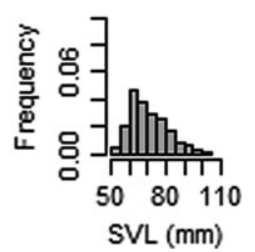

Figure 2. Histograms illustrating body size distribution of the different subsets of the sample. A, unit 'N'; B, unit 'C'; $\mathrm{C}$, unit 'H'; D, unit 'S'; E, unit 'c1'; F, unit 'P'; G, unit 'G'; H, all species together.

$\mathrm{N}$ and $\mathrm{C}$ (putative hybrids) were included in a separate category $(\mathrm{H})$. Because species in the group show sexual dimorphism in size, we restricted all analyses to males with well-developed secondary sexual characteristics (presence of nuptial pads and hypertrophied arms relative to females of similar sizes). 


\section{DATA ACQUISITION}

We obtained photographic images for all individuals, adapting the methodology described by Ivanović et al. (2008). We positioned each specimen with its jaw line parallel to the photographic plane and obtained head images with a Canon Power Shot G9 digital camera fixed over the photographic plane $20 \mathrm{~cm}$ from the specimen at 12-megapixel resolution and with macro function. We positioned each specimen at the centre of the optical field to reduce and equalize distortion. We chose to investigate head shape because it includes many characters used in studies of intra- and interspecific variation of amphibians (e.g. Clemente-Carvalho et al., 2008, 2011; Vieira et al., 2008; Ivanović et al., 2009, 2011).

With the obtained images we created two separate data sets, one consisting of 12 landmarks positioned on each specimen: (1) top of the rostrum, (2) beginning of the loreal crest, (3) junction point between the loreal crest and the anterior edge of the eye, (4) junction point between the supra-tympanic edge and posterior edge of the eye, (5) midpoint between landmarks ' 3 ' and ' 4 ', (6) top of the paratoid gland, (7) bottom of the paratoid gland, (8) beginning of the supra-tympanic edge, (9) beginning of the cephalic crest, (10) end of the cephalic crest, (11) midpoint of the loreal crest and (12) landmark positioned in the mandible at $90^{\circ}$ degrees point ' 11 ' (Fig. 3A); and another with 89 semi-landmarks (Fig. 3B). While landmarks are used on homologous, unambiguous, repeatedly identifiable structures, semi-landmarks are points with estimated positions (Bookstein, 1997; Adams, Rohlf \& Slice, 2004; Mitteroecker \& Gunz, 2009; Clemente-Carvalho et al., 2011), generally used when landmarks alone cannot describe biological forms or patterns (Oxnard, 1978). We used semilandmarks to characterize the following regions: the mandibular arch (MA), supra-tympanic edge (STe), inner edge of the eye (ieE), loreal crest (LC) and parotoid gland (PG) (see Fig. 3B). Because spacing between semi-landmarks is arbitrary (Croix et al., 2011), we aligned these configurations with a perpendicular projection (Sampson et al., 1996; Bookstein et al., 2002; Sheets, Keonho \& Mitchell, 2004). In this method, the differences in semi-landmark positions between the reference and each specimen configuration are removed by estimating the

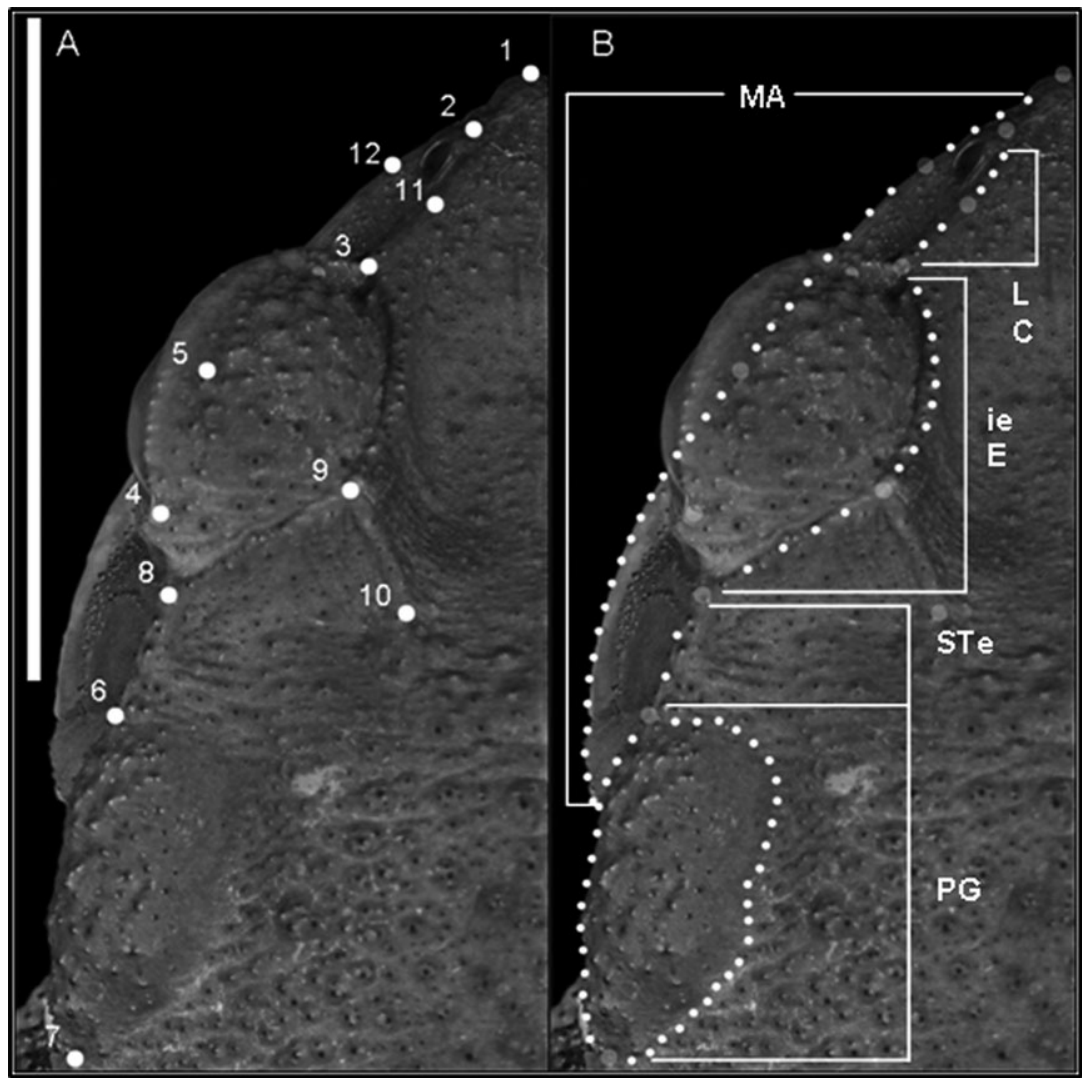

Figure 3. Landmarks (A) and semi-landmarks (B) used in this study (see text for details) plotted on the head of specimens of the Rhinella crucifer group (CFBH 18815, Teresópolis, RJ). Scale bar $=25 \mathrm{~mm}$. 
distinction tangential to the curve and removing the component of the difference that lies along this tangent (Sheets et al., 2004). We used the TPS relative warps (TpsRW) software version 1.44 (Rohlf, 2005) to slide the semi-landmarks along their respective curves and minimize the distances between subject and reference (Bookstein et al., 2002; Clemente-Carvalho et al., 2011).

The choice of landmarks and semi-landmarks used here was based on diagnostic characters defined for the different species in the group as a whole (Baldissera et al., 2004; Vieira et al., 2008; Vaz-Silva et al., 2012). We positioned the landmarks and semi-landmarks on images of each specimen (the same image being used for each procedure), with the program TPSdig2 (http://life.bio.sunysb.edu/morph) (Rohlf, 2004, 2005). Aiming to control possible sources of error, all landmarks and semi-landmarks were positioned by the same person (L.N.B.).

\section{DATA ANALYSES}

Erroneous placement of landmarks can lead to spurious interpretation of the patterns and processes under investigation. In this scenario, quantification of measurement error is an important step for morphometric work. We quantified error by employing the Procrustes ANOVA (Goodall, 1991; Klingenberg $\&$ Monteiro, 2005). For this, we positioned landmarks twice in a subsample consisting of 70 randomly selected specimens. We then subjected both datasets to a Generalized Procrustes Analysis (GPA, commonly known as 'Procrustes fit', see below), and the Procrustes-fitted configurations were used in repeated-measures Procrustes ANOVA. The measurement error is the percentage of variation resulting from the division between the mean square error (MSE) by the mean square (MS) of the lowest level of biological significance (in the specific case: individuals) (see Table 1). We assumed that error below $30 \%$ is acceptable. All analyses were performed in the software MorphoJ Version 2.0 (Klingenberg, 2011).
To describe and quantify variation in shape within the group we first statistically control for the effects of body size on the landmark and semi-landmark data. For this step we applied standard geometric morphometric approaches to align the configurations of landmarks and semi-landmarks before any analysis. We conducted a GPA to align the landmark configurations of all specimens with the software MorphoJ Version 2.0 (Klingenberg, 2011). The GPA preserves all information about shape variability among specimens while removing information unrelated to shape (position, scale and orientation) (Clemente-Carvalho et al., 2008, 2011; Ivanović et al., 2008). After a multivariate regression of the landmark and semi-landmark data, a $\ln$ (centroid size) was performed with the same software. MorphoJ allows pooling of variance by taxonomic unit or geographical unit in the computation of the regression statistics, and a permutation test is available for assessment of the probability of the regression (if it is rejected, no further size adjustment is necessary). As the results of the regressions performed were not significant (see Data S1), no allometric correction was necessary and the coordinates resulting from the Procrustes superimposition were used in further analyses. A plot of head length against body length was included as a complement to the multivariate regression (see Fig. 4).

To determine if there is variation in shape among the group as a whole and to explore the relative amount of variation in cranial shape, we used a variance-covariance matrix and performed a principal components analysis (PCA) (Bookstein, 1991; Rohlf, 1993; Clemente-Carvalho et al., 2011). Principal components were used as new shape variables to reduce the dimensionality of the dataset and to produce independent variables (Baylac \& Friess, 2005). We visualized the principal cranial shape differences among the species on deformation grids (Rohlf, 1993; Adams et al., 2004; Klingenberg, 2013) created in the software MorphoJ Version 2.0 (Klingenberg, 2011). In addition, to ascertain whether changes in form are sufficient to differentiate between

Table 1. Procrustes ANOVA results

\begin{tabular}{lllrrrr}
\hline Effect & SS & MS & d.f. & $F$ & $P$ & $\%$ Variance \\
\hline Individual & 0.33457990 & 0.0009293886 & 18 & 6.09 & $<0.0001$ & 0.3323 \\
Replicates & 0.03445240 & 0.0017226619 & 1 & 0.99 & 1.8535 \\
Residual & 0.96664140 & 0.0002543793 & 190 & & & \\
\hline
\end{tabular}

Mean square (MS) is the amount of variation from the one higher level in the hierarchy. The $F$ values represent the comparison of each MS to the one lower level of MS which could be the source of error. \%Variance represents the division of the mean square of the lowest level of biological significance by the mean square error for the ANOVA. 


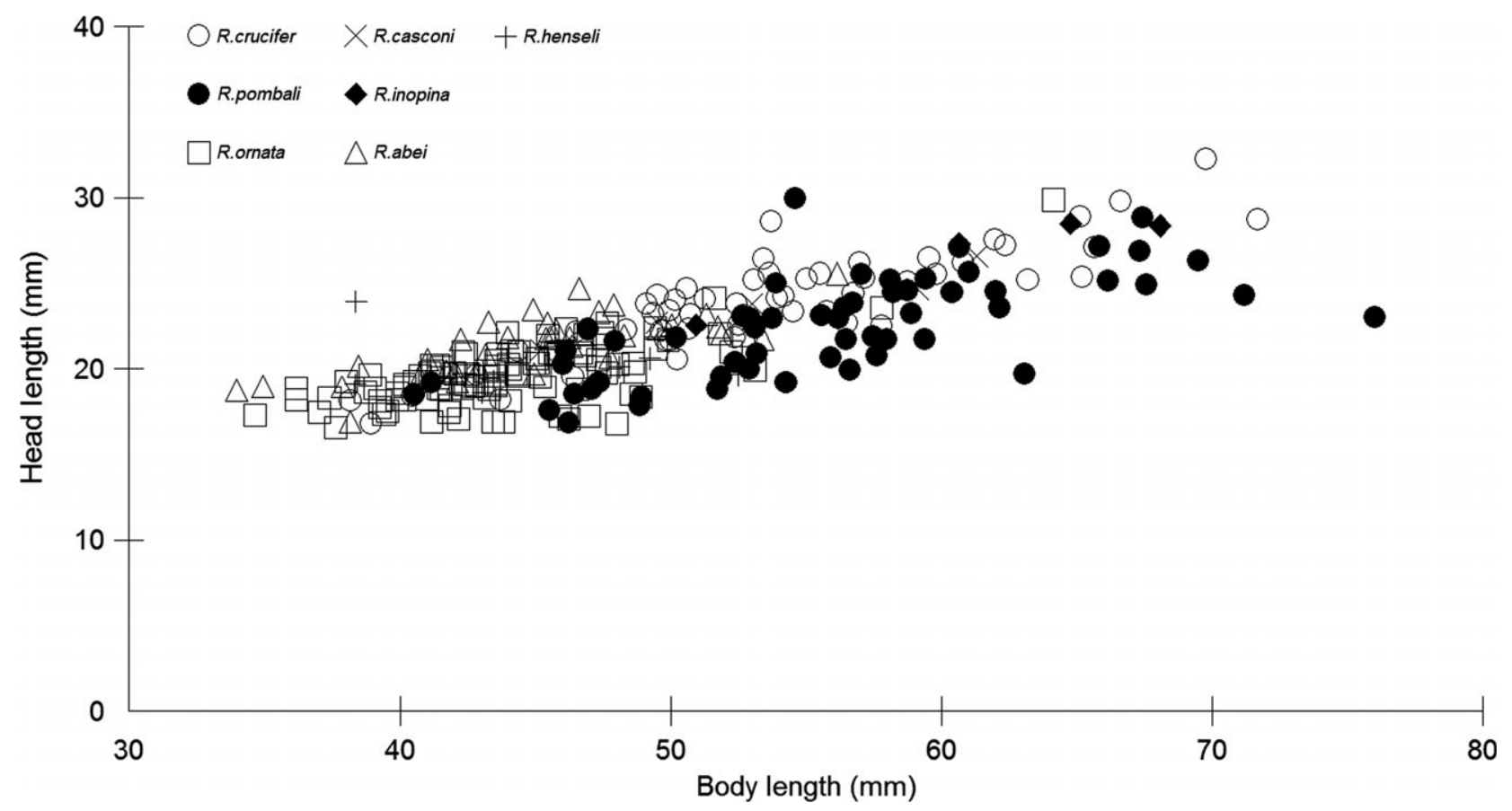

Figure 4. Scatterplot of head length against body length. Body length = snout-vent length - head length

predefined categories, we used canonical variate analyses (CVAs), with paired permutation tests based on Procrustes and Mahalanobis distances (Gould \& Johnston, 1972). To first explore the effects of relatedness we performed CVA considering all genetic categories separately $(\mathrm{G}, \mathrm{P}, \mathrm{N}, \mathrm{C}, \mathrm{S}, \mathrm{H}$ and c1), and then proceeded with CVA hierarchically by clustering categories according to genetic relatedness (following the topology in Thomé et al., 2012; Fig. 5). Finally, we performed a CVA including only the closest genetic units according to mitochondrial DNA genetic distances in Thomé et al. (2012). We conducted permutation tests with 10000 permutations. For all CVA and permutation tests we used the software MorphoJ Version 2.0 (Klingenberg, 2011).

To further investigate how phylogenetic history affects variation in head shape, we first mapped the principal components on a phylogeny using Maddison's method (Maddison, 1991; McArdle \& Rodrigo, 1994; Rohlf, 2001). Two phylogenetic trees for the Rhinella crucifer group were used, one with topology based on the original mitochondrial DNA (putative hybrids not included, Fig. 5A), and an alternative tree with the closest genetic units included as a collapsed clade (putative hybrids included, Fig. 5B). The phylogenetic trees have been superimposed onto a plot of the first two principal components (PC1 and PC2) derived from the variance-covariance matrix among all specimens used as representatives of clades. To test for phylogenetic signal we reconstructed the morphometric data for ancestral nodes of the trees with squared-change parsimony (Maddison, 1991; Cole, Lele \& Richtsmeier, 2002; MacLeod, 2002; Cardini \& Elton, 2008; Klingenberg \& Gidaszewski, 2010). The null hypothesis (absence of phylogenetic signal) was then simulated by permutation: specimen configurations are randomly reassigned to the terminal nodes of the phylogeny and then mapped onto the phylogeny to calculate the total tree length in units of morphometric distance. The proportion of permuted data sets in which the sum of squared changes is shorter or equal to the value obtained for the original data is the $P$ value for the test. For reconstruction of the morphometric data and tests of phylogenetic signal we used the MorphoJ software Version 2.0 (Klingenberg, 2011).

Second, we explored shape variation controlling for phylogenetic covariance with a phylogenetic PCA (pPCA) (Revell, 2009; Polly et al., 2013). We used pPCA both to explore the shape variation that is free from phylogenetic signal and to relate it to environmental factors. The pPCA is similar to ordinary PCA, but the covariance matrix is inversely weighted by the phylogeny and the space is centred on the estimated phenotype of the root node of the tree. The inverse weighting of the pPCA corrects for shared phylogenetic history in constructing the axes, producing scores that represent the remaining variation. We then contrasted the values of the first two phylogenetic principal components of each specimen 
A

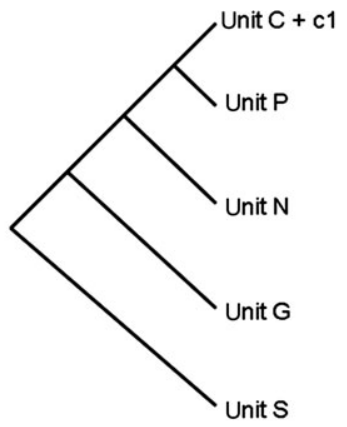

C

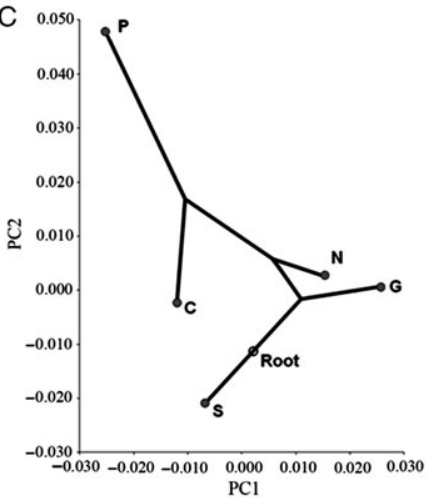

$\mathrm{E}_{0.060}$

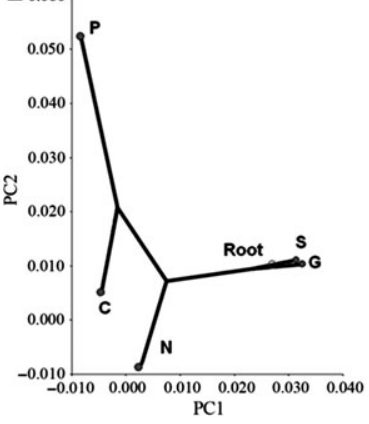

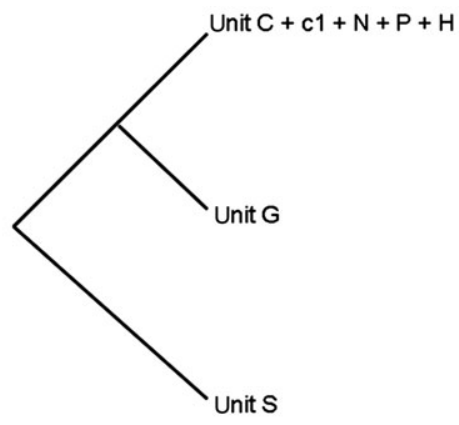
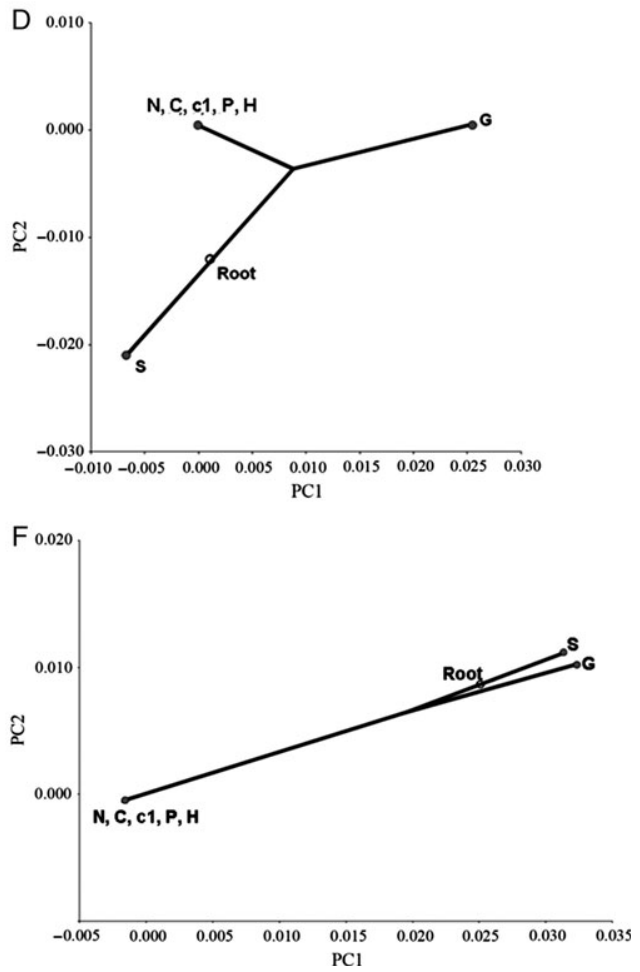

Figure 5. Phylogenetic trees for the Rhinella crucifer group considered in this study. A, topology of the original mitochondrial DNA tree from Thomé et al. (2012); B, alternative tree with closest genetic units collapsed into a single clade. C-F, plots showing reconstruction of evolutionary changes in head shape of the species of the Rhinella crucifer group according to both mitochondrial trees. C, reconstruction using landmarks and the original tree; D, reconstruction using landmarks and collapsed tree; E, reconstruction using semi-landmarks and the original tree; F, reconstruction using semi-landmarks and collapsed tree.

against environmental distance using partial Mantel tests (Smouse, Long \& Sokal, 1986) (see below). For the pPCA analyses, and to generate the graphs, we used the RStudio language and environment for statistical computing version 5.13 for Windows ( $\mathrm{R}$ Development Core Team, 2014; http://www.R-project. org) and the packages ape (Paradis, Claude \& Strimmer, 2004) and phytools (Revell, 2009, 2012), for the $\mathrm{R}$ environment.

Finally, to test the influence of physical environment on morphology, we applied the partial Mantel test of matrix association (Smouse et al., 1986). We used the matrix of scores generated by pPCA as the dependent matrix. The independent matrix was that of the environmental data. Between-locality environmental distance was expressed by pairwise simple Euclidean distance for a set of environmental variables that are not significantly correlated and that describe elevation and climate (Gvozdík, Moravec \& Kratochvíl, 2008) in the Brazilian Atlantic forest (Marcelino et al., 2009). The environmental variables were elevation (Alt), annual mean temperature (AnnMTemp), temperature annual range (TemAnnRge), annual precipitation (AnnPrec), precipitation of the 
wettest month (PreciWetMon) and precipitation of the wettest quarter (PrecWetQtr), and were obtained from the bioclimatic database 'Worldclim' at a spatial resolution of 30 arc-seconds (http://www.worldclim. org/) (Hijmans et al., 2005). The macroclimatic data of 'TemAnnRge' and 'AnnPrec' show the annual climate cycle experienced by a population (Gvozdík et al., 2008). The partial Mantel tests were performed with 10000 randomizations and $\alpha=5 \%$ in the package Ecodist 1.2.9 (Goslee \& Urban, 2007) in the RStudio language and environment for statistical computing version 5.13 for Windows (R Development Core Team, 2014, http://www.R-project.org). For both analyses we considered the original mitochondrial DNA (putative hybrids not included, Fig. 5A) and an alternative tree with the closest genetic units included as a collapsed clade (putative hybrids included, Fig. 5B).

\section{RESULTS}

Procrustes ANOVA was performed for total of 70 specimens of and the proportion of variation related to this effect was low (see Table 1). Each specimen was imaged once and each image was digitized twice, producing 140 raw coordinate data for the head. Measurement error was estimated from this Procrustes ANOVA by considering individual as the main source of variation, nested by variation in digitized replicates, and residuals.

In the PCA with landmark data the two-first components explained $52.5 \%$ of the variation in head shape. The biplot shows overlap of the clouds of points representing all genetic units, as shown in the Supporting Information (Data S2A). Changes in shape, depicted by the first principal components, mainly encompass displacement of landmarks representing the cephalic crests and eye, as shown in the deformation grids (Fig. 6). Specimens from genetic categories $\mathrm{N}$ and $\mathrm{H}$ display more prominent and well-developed cephalic crests while the specimens from $\mathrm{C}, \mathrm{c} 1$ and $\mathrm{S}$ display gradually underdeveloped crests, respectively. The representatives of category G have less conspicuous cephalic crests. Individuals of categories $\mathrm{N}, \mathrm{C}$ and $\mathrm{H}$ also present similar, broader eyes, while G, P and $\mathrm{S}$ display smaller and narrower eyes. For the semi-landmarks, the two-first components explained $38.3 \%$ of the total variance and the categories in the biplot are also broadly overlapping, as shown in Data S2B. The main changes in shape consist of the displacement of the parotoid gland and the eye, with some differences related to the contours of the mandibular arch. Specimens of categories $\mathrm{N}, \mathrm{C}$ and $\mathrm{H}$ have similar spherical parotoid glands of larger size whereas $\mathrm{S}$ specimens display a thinner and longer parotoid gland. $\mathrm{G}$ and $\mathrm{P}$ also display discrepant paratoid shapes, smaller than in the other groups and much broader anteriorly in G, and with two distinguishable lobes in P (Fig. 6).

In the CVA performed with landmarks, the first two canonical variates accommodated $70.73 \%$ of the variation when all genetic units were considered separately, with the confinement of the scores for category $\mathrm{S}$ to more peripheral regions of the multivariate space (Fig. 7A). In the CVA with only phylogenetically closest units (categories $\mathrm{N}, \mathrm{P}, \mathrm{H}, \mathrm{C}$ and $\mathrm{c} 1$ ), the first and second variates accommodated $75.09 \%$ of the variation and showed slightly better separation of categories $\mathrm{P}$ and $\mathrm{G}$, although with overlap (Fig. 7B). Finally, in the CVA including clustered genetic units (categories [N, P, H, C, and, c1]) plus G and $\mathrm{S}$, the first two canonical variables accommodated $91.79 \%$ of the variation and there was little overlap among all categories in the biplot (Fig. 7C). In the CVAs performed with the semi-landmark dataset, the first two canonical variables accommodated $52.62,60.16$ and $82.17 \%$ of the total variation in the analyses considering all units separately, considering only the closest genetic units and considering clustered genetic units together, respectively. In the first, the biplot shows some overlap of categories $\mathrm{N}, \mathrm{P}, \mathrm{H}, \mathrm{C}$ and $\mathrm{c} 1$, and clear isolation of categories $\mathrm{S}$ and $\mathrm{G}$ (Fig. 7D). In the second CVA there is almost complete separation of $\mathrm{N}$ and $\mathrm{H}$, and overlap of the remaining categories (Fig. 7E), whereas the third biplot shows complete isolation of categories (Fig. 7F). Permutation tests based on Mahalanobis distances support that the variation in form is sufficient to differentiate among the considered categories, whereas permutation tests performed using Procrustes distances did not yield significant results in some comparisons involving categories G, $\mathrm{c} 1$ and $\mathrm{P}$ (Table 2).

Mapping of the scores of the first two principal components of the landmark dataset onto the two alternative phylogenies yielded different results. In the reconstruction of shape based on the original phylogeny, the plot shows a conspicuous divergence between the genetic category $\mathrm{P}$ and the others, described by the second principal component (Fig. 5C), whereas differences between $\mathrm{C}$ and $\mathrm{S}$ and between $\mathrm{N}$ and $\mathrm{G}$ are described by the first principal component. The null hypothesis of no phylogenetic signal could not be rejected ( $P=0.282$, Table 3$)$. The reconstruction onto the collapsed phylogeny shows a clear divergence between categories $[\mathrm{N}, \mathrm{P}, \mathrm{H}, \mathrm{C}$ and c1], $\mathrm{G}$ and S. [N, P, H, C and $\mathrm{c} 1]$ and $\mathrm{G}$, and $\mathrm{S}$ and $\mathrm{G}$, are distinguished primarily by the first principal component (Fig. 5D). Between categories [N, P, H, C and c1] and $\mathrm{S}$ the divergence lies mainly in the second component. The permutation test confirmed significant phylogenetic structure in the data $(P<0.0001$, 

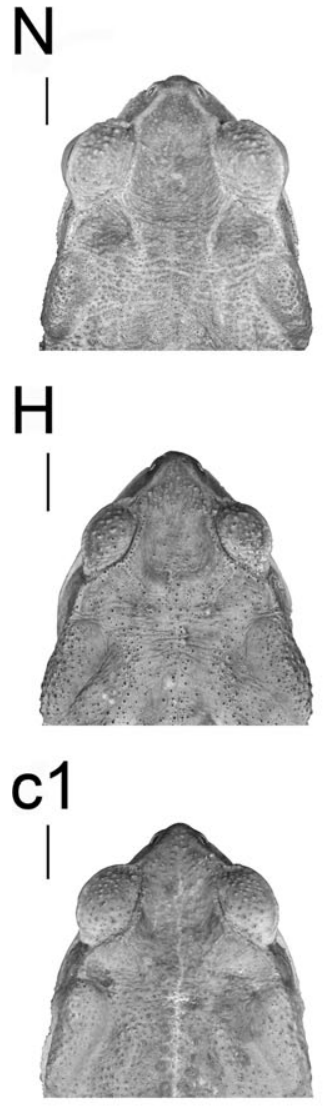
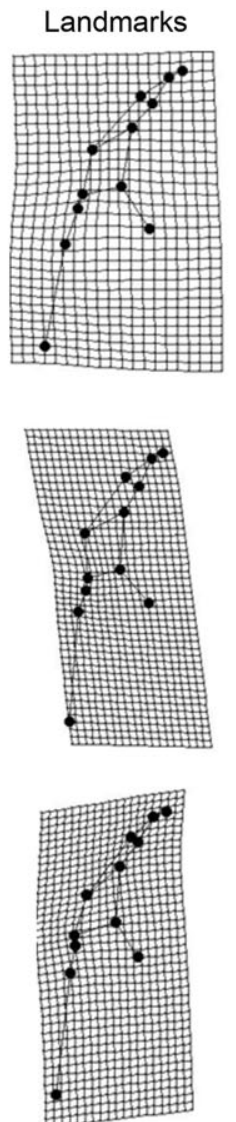
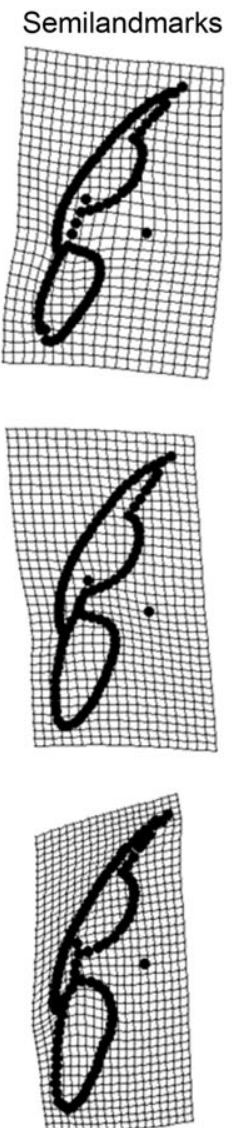
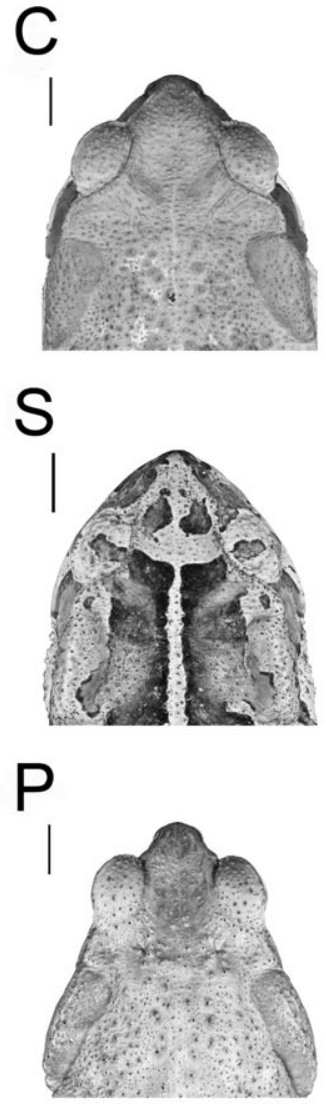

Semilandmarks
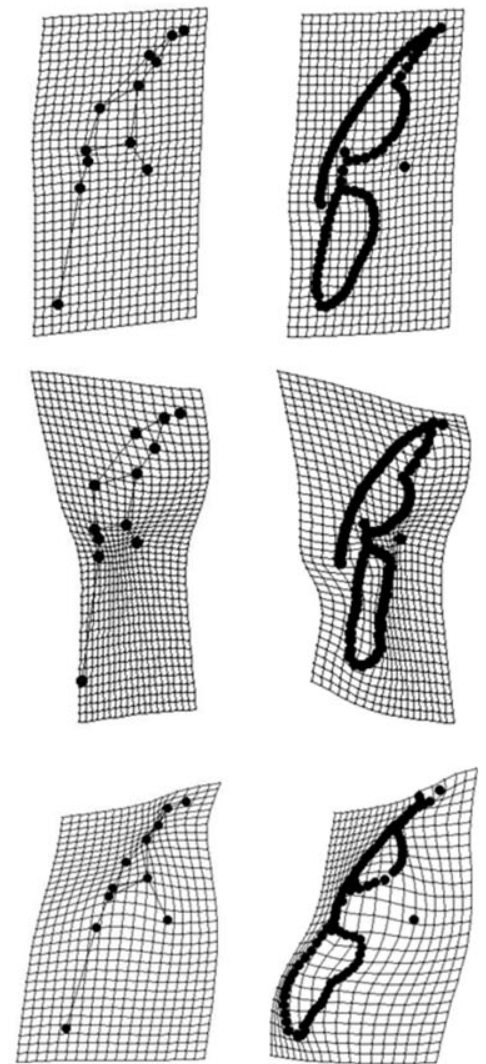
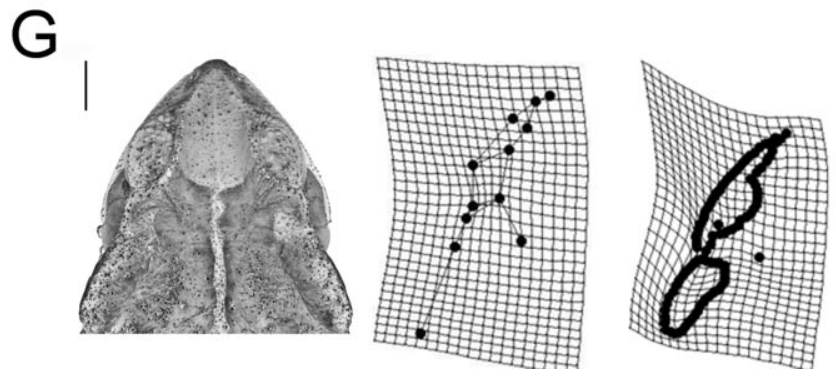

Figure 6. Images of the dorsum of the head of representatives of each analysed category of the Rhinella crucifer group and corresponding deformation grids implied by the first principal component. N, North unit $(\mathrm{CFBH}=2583)$; C, Center unit $(\mathrm{CFBH}=15383) ; \mathrm{H}$, 'Hybrids' (PUC = 7537); S, South unit $(\mathrm{CFBH}=20277)$; c1, centre 1 unit (subclade) $(\mathrm{CFBH}=18175)$; $\mathrm{P}$, 'Peruacu' unit (MZUSP = 142105); G, 'Guaramiranga' unit $(\mathrm{CFBH}=28172)$.

Table 3). In the analysis generated with semi-landmarks and the original phylogeny, the plot shows a similar disposition as for the analysis with landmarks (Fig. 5E). Overall there is a clear distinction between [N, P, H, C and $\mathrm{c} 1]$ and $\mathrm{S}$, and between $[\mathrm{N}, \mathrm{P}, \mathrm{H}, \mathrm{C}$ and $\mathrm{c} 1]$ and $\mathrm{G}$, described by the first principal component (Fig. 5F). The difference between $\mathrm{S}$ and $\mathrm{G}$ was extremely subtle. In either case, the null hypothesis of no phylogenetic signal cannot be rejected ( $P$-values of 0.365 and 0.335 , respectively).

For pPCAs generated based on the tree reconstructed with mitochondrial data, the percentage of variance explained by the first two axes was $56.66 \%$ for the dataset with landmarks and $37.33 \%$ for the dataset with semi-landmarks, as shown in the Supporting Information (Data S3 and S4). When the phylogenetic analysis of principal components was weighed based on data from the collapsed tree, the percentage of changes explained in morphology was $58.03 \%$ for the dataset with landmarks and $36.75 \%$ for the dataset with semi-landmarks (Data S3A and S4A). For morphometric pPCA-based distances obtained using landmarks and the original phylogeny, the associations were significant for all 

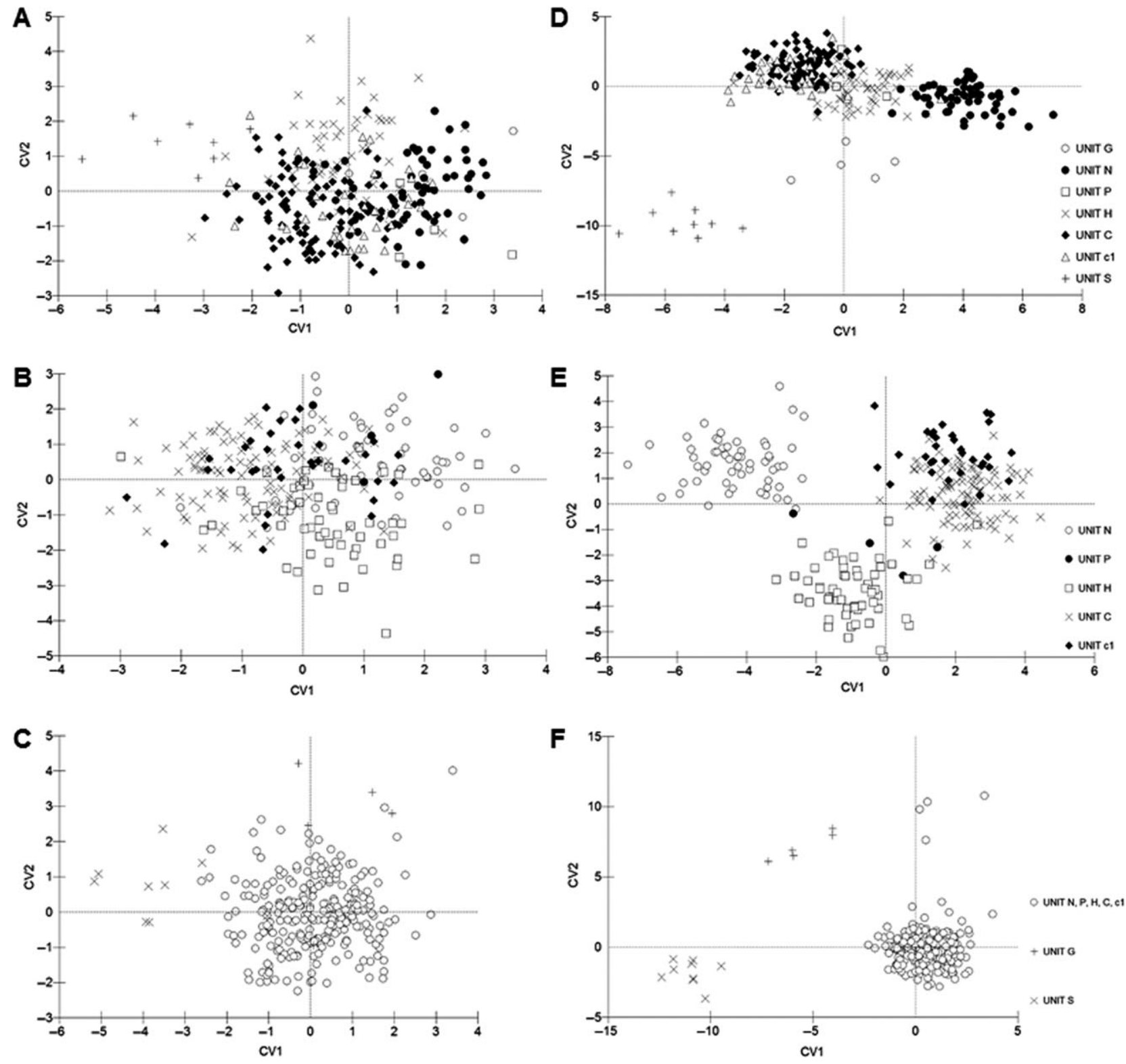

Figure 7. Scatterplots of canonical variate scores for the dataset with landmarks (A, B, C) and semi-landmarks (D, E, F) of the Rhinella crucifer group. In A and D, all categories are considered separately, in B and E only categories corresponding to closely related genetic units are considered, and in $\mathrm{C}$ and $\mathrm{F}$ closely related genetic units are considered as a single category.

variables, except for the variable annual precipitation and pPC1_semi (Table 4). Using the collapsed phylogeny, morphometric pPCA-based distances were associated with altitude, annual mean temperature, temperature annual range, annual precipitation, precipitation of the wettest month and precipitation of the wettest quarter, with the exception of pPC2, which was not significantly associated with annual precipitation (Table 4). For the pPCA with semi-landmarks, all the environmental variables were associated with the differences between morphological values with the exception of $\mathrm{pPC} 2$, which was not significantly associated with temperature annual range (Table 4).

\section{DISCUSSION}

\section{HEAD SHAPE VARIATION IN THE RHINELLA CRUCIFER GROUP}

From the ordination of scores of the analysed specimens, it is evident that the proportion of the total 


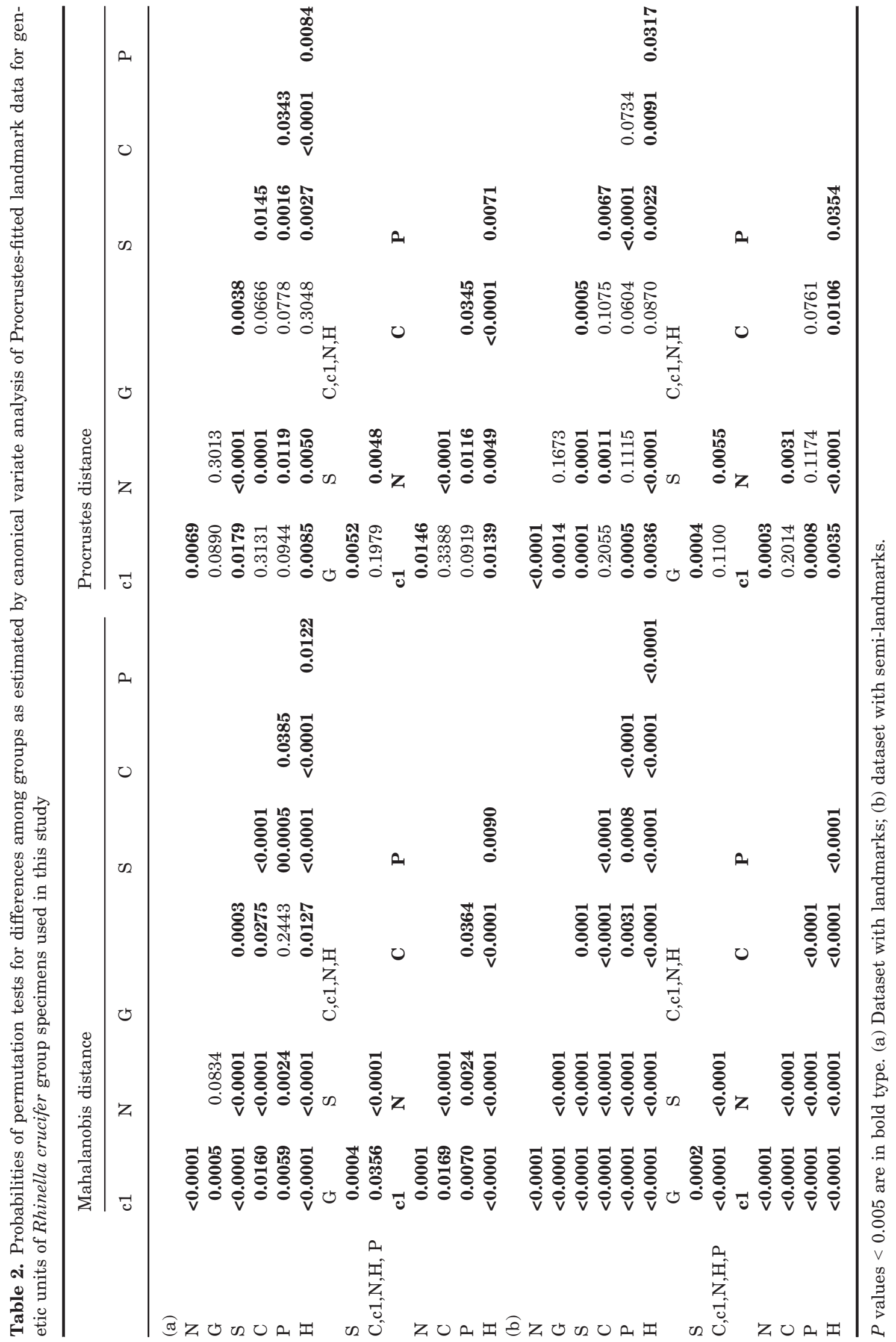


shape variation that is explained by the principal components is limited. This may be due to the recent diversification of the group (Thomé et al., 2010), the typical conservatism in the skull of bufonids (Martin, 1972; Pramuk, 2006), the method used, which may have been inefficient in recovering shape patterns in these animals, or a combination of the three. Nonetheless, shape changes are detectable and related to specific structures in the head of specimens, as shown in the deformation grids. Analysis of landmark data revealed that specimens from the different genetic units differ in the shape of the cephalic crests and eye, relative to a consensus configuration. Analysis of semi-landmarks also showed changes in the shape of the parotoid gland, eye and contour of the mandibular arch. Note that Baldissera et al. (2004) used variation in the same structures qualitatively as taxonomic characters to differentiate among species in the group. This is not surprising because species in Baldissera et al. (2004) and the categories considered in the present paper show considerable overlap (see discussion in Thomé et al., 2012). Furthermore, it highlights the ability of trained taxonomists to perceive subtle morphological variation despite the lack of guidance from genetic markers.

Table 3. Tree lengths computed with squared-change parsimony and $P$ values for the permutation tests of phylogenetic signal $(*$ = statistically significant value)

\begin{tabular}{lll}
\hline Phylogeny & $\begin{array}{l}\text { Landmarks } \\
\text { Tree length, } P\end{array}$ & $\begin{array}{l}\text { Semi-landmarks } \\
\text { Tree length, } P\end{array}$ \\
\hline $\begin{array}{l}\text { Mitochondrial tree } \\
\text { Collapsed tree }\end{array}$ & $0.00631,0.282$ & $0.00702,0.365$ \\
\hline
\end{tabular}

In the analyses including prior information (CVAs), the proportion of the variation among categories accommodated by the first canonical variates was usually large, being larger for landmarks than for semi-landmarks. Conversely, the biplots showed more definition in the separation of categories when the semi-landmarks were used. Both landmarks and semi-landmarks showed a similar pattern in terms of the amount of variation accommodated by the first two canonical variates in the different comparisons: the percentage of variation accommodated was larger in the comparisons in which we clustered the closest genetic units as a single category. This might be due to the fact that category $\mathrm{H}$, representing specimens from the transition zone between $\mathrm{N}$ and $\mathrm{C}$, is not a natural group and may include specimens belonging to each of these two genetic units and hybrids with transitional characteristics. Therefore, it is expected that analyses allowing for the comparison of this category with categories $\mathrm{N}$ and $\mathrm{C}$ would show a lack of discrimination.

Overall, our analyses indicate that there is sizefree variation in the shape of the head of specimens in the Rhinella crucifer group, and that morphological changes are associated with specific structures. Variation is subtle, but sufficient to statistically differentiate among genetically defined units in most cases. The difference in number of analysed specimens among groups may be the cause of statistical discrepancies in significance in each comparison, as shown by Pillar (1999). In other words, the variation in sample size, in particular, affects the probability of committing type II statistical error.

Morphological analyses of single structures may be difficult. In the work of Clemente-Carvalho et al. (2011), some variant patterns in morphology were not detected with the use of landmarks alone. In

Table 4. Results of Mantel tests for association between morphological differentiations across specimens of the species of the Rhinella crucifer group vs. six environmental distance variables (see text for details)

\begin{tabular}{|c|c|c|c|c|c|c|}
\hline \multirow[b]{2}{*}{ Dependent variable } & \multicolumn{6}{|c|}{ Explanatory variable } \\
\hline & Elevation & AnnMTemp & TempAnnRge & AnnPrec & PrecWetMon & PrecWetQtr \\
\hline pPC1\#12_full mitochondrial tree & $0.001^{*}$ & $0.03 *$ & $0.03 *$ & $0.006^{*}$ & $0.01 *$ & $0.006^{*}$ \\
\hline pPC2\#12_full mitochondrial tree & $0.004^{*}$ & $0.01 *$ & $0.04 *$ & $0.0001^{*}$ & $0.03 *$ & $0.02 *$ \\
\hline pPC1\#semi_full mitochondrial tree & $0.02 *$ & $0.006^{*}$ & $0.03^{*}$ & n.s. & $0.01^{*}$ & $0.001^{*}$ \\
\hline pPC2\#semi_full mitochondrial tree & $0.01^{*}$ & $0.009 *$ & $0.006 *$ & $0.04^{*}$ & $0.02 *$ & $0.006^{*}$ \\
\hline pPC1\#12_collapsed & $0.02 *$ & $0.01 *$ & $0.02 *$ & $0.01^{*}$ & $0.01 *$ & $0.005^{*}$ \\
\hline pPC2\#12_collapsed & $0.02 *$ & $0.03 *$ & $0.03 *$ & n.s. & $0.009 *$ & $0.01 *$ \\
\hline pPC1\#semi_collapsed & $0.003^{*}$ & $0.01 *$ & $0.02 *$ & $0.02 *$ & $0.03 *$ & $0.03^{*}$ \\
\hline pPC2\#semi_collapsed & $0.007 *$ & $0.01 *$ & n.s. & $0.0008^{*}$ & $0.003^{*}$ & $0.009 *$ \\
\hline
\end{tabular}

Dependent variables are the first two axes from pPCA (for both datasets). Mantel correlation values are given where significant $(* P<0.005$; n.s., not significant). 
particular, landmark-based geometric morphometric approaches may be insufficient for analysing structures without clear points of homology. In such cases, the addition of semi-landmarks may provide new information on curves and surfaces, allowing for better descriptions and finer analysis of the complexity of biological form (Gunz, Mitteroecker \& Bookstein, 2005; Perez, Bernal \& Gonzalez, 2006; Gunz et al., 2009). In our analyses, landmarks and semi-landmarks highlighted shape changes associated with different structures, showing that the analyses of both types of data are complementary in portraying the geographical nature of morphological differentiation.

\section{SHAPE IS PARTIALLY EXPLAINED BY GENETIC RELATEDNESS}

Phylogenetic signal is defined as the degree to which phylogenetic relatedness among taxa is associated with their phenotypic similarity (e.g. Blomberg, Garland \& Ives, 2003; Cardini \& Elton, 2008). Therefore, if closely related taxa are morphologically more similar than more distant taxa, phylogenetic signal may be detected. We first approached this by conducting CVA hierarchically. Analyses comparing all genetic categories accommodated less variation than analyses in which we clustered the most closely related categories, as one would expect in the presence of phylogenetic signal (although fewer groups result in fewer CVs, which may cause higher variation in the first CV). Also, the biplots show more proximity (and overlaps) of the categories $\mathrm{N}, \mathrm{P}, \mathrm{C}, \mathrm{c} 1$ and $\mathrm{H}$, whereas categories $\mathrm{G}$ and $\mathrm{S}$ are confined to more peripheral regions of the multivariate space. Category c1 represents a haplogroup within genetic unit $\mathrm{C}$ whose geographical distribution is somewhat concordant with the distribution of Rhinella abei, a species described by Baldissera et al. (2004) using morphological criteria. This species was not detected in the multilocus analyses of Thomé et al. (2012) and its recognition under a phylogenetic species concept is pending more genetic markers. It is impossible, however, to confirm that the overlap between the scores of specimens from unit $\mathrm{c} 1$ and $\mathrm{C}$ indicates that this category has no biological meaning. Interestingly, Baldissera et al. (2004) obtained a similar pattern in their traditional morphometric analysis, with the scores of $R$. abei being nested within the polygon of $R$. ornata, here included as category C. For G and $\mathrm{S}$, the most divergent genetic units in the group according to the mitochondrial DNA, interpretation of the results was more straightforward, as all biplots showed a trend of isolation of their respective scores. However, scores from $\mathrm{P}$ are also usually fairly isolated, even though genetic unit $\mathrm{P}$ is sister to $\mathrm{C}$, denoting unexpected variation in shape for this genetic unit.

We applied a more rigorous test by mapping the principal components on a phylogeny. We then assessed statistical significance by simulating the hypothesis of no phylogenetic signal using permutations. We were able to detect the effect of relatedness with the landmark dataset, but only when considering the closest genetic units as one taxon, with the two remaining taxa showing more strongly defined shape changes as genetic divergence increased. It is possible that the lack of significance in the analysis based upon the original tree is caused by the morphological dissimilarity of $\mathrm{P}$ compared with all other units. The failure in rejecting the null hypothesis of no phylogenetic signal with the semi-landmark dataset is intriguing, as these seem to graphically provide better-defined results in the CVAs (Fig. 7). Taking all the results together, it is only possible to confirm that the evolutionary history of the group explains the variation in the shape of the head to a limited extent.

\section{INFLUENCE OF PHYSICAL ENVIRONMENT}

The geographical distribution of species or groups of closely related species may be broad enough that various characteristics of their environment vary within their range (e.g. Keller et al., 2013). Phylogenetic comparative methods are often employed for studying the relationship between phenotypes and environment (sensu Gould \& Vrba, 1982). These methods allow for the partitioning of phenotypic variation into phylogenetic (endogenous) and nonphylogenetic (exogenous) components (Levin, 1992; Levin \& Pacala, 1997; Martins \& Hansen, 1997; Felsenstein, 2003). However, the assumption that the exogenous component is always related to the physical environment can be equivocal (Polly et al., 2013), making it necessary to determine the degree of direct influence of each variable on the changes in shape. Elucidation of the direct mechanism behind the influence of environment over development and, consequently, adult morphology is beyond the scope of our study. Nevertheless, we minimized a possible effect of relatedness (with the phylogenetic PCA) and tested for associations of local climates and elevation with shape because it has been suggested that morphology in anurans is particularly sensitive to environmental conditions (Marcelino et al., 2009). A significant proportion of the variation in head morphology among particular species can be statistically explained by the majority of the environmental factors taken into account (see Table 3 for details). It suggests that variability in the physical environment constitutes an important factor in the determination 
of head morphology and should be considered as a source of variation. More specifically, it appears that populations of the same genetic category living in the areas differing the most in environmental conditions display more dissimilar morphotypes, whereas individuals from different genetic categories occupying areas with similar environmental characteristics may display somewhat similar cranial shapes. Particularly, some individuals of $\mathrm{N}$ and $\mathrm{C}$ (and from $\mathrm{C}$ and $\mathrm{c} 1$ ) from regions geographically adjacent seem less distinguishable in morphospace (see Supporting Information for geographical origins of specimens). An equivalent response by different species to a shared environment, assuming that climate and elevation in geographically adjacent regions are probably similar, is the most plausible explanation for this morphological similarity. Alternatively, the efforts of Thomé et al. (2012) may have been insufficient to properly delimit the zone of putative hybridization between $\mathrm{N}$ and $\mathrm{C}$, and the similarity between categories near the zone of contact of their ranges could be explained by interspecific hybridization and subsequent introgression of morphotype-mediated genes (sensu Grant \& Grant, 2002). Although the correlation observed between body shape and environmental variables suggests an important role for environmental conditions in the production of morphological variation in these taxa, many interpretations of our results are possible. Future experimental work (e.g. common garden or reciprocal transplant experiments in conjunction with quantitative genetics) may identify the evolutionary and ecological processes responsible for the observed matching between the environment and morphology in examined species (Gvozdík et al., 2008). Such experimental approaches could determine whether similar morphology is caused by a shared plastic responses to environmental conditions.

\section{CONCLUSIONS}

In this study we used geometric morphometrics to reassess morphometric variation in the Rhinella crucifer group and to consider its evolutionary history and local variation relative to environmental conditions (e.g. climate and altitude). Our main questions were: (1) Is there size-free shape variation in the group? (2) If so, can this variation be explained by genetic relatedness. (3) Is shape variation influenced by local variation of the physical environment? Our results revealed that there is size-free shape morphological variation in toads of the Rhinella crucifer group. Variation is subtle, but sufficient to differentiate among genetically defined units in most cases. Shape changes are related to specific structures in the head of specimens defined by landmarks and semi-landmarks, highlighting changes associated with different structures, showing that the analysis of both types of data is complementary. Variation can be explained both by genetic relatedness and by local physical environment. The effects of relatedness were first revealed by hierarchical CVA, where analyses comparing all categories accommodated less variation than analyses in which we clustered the most closely related categories. Also, biplots showed restriction of more divergent categories to peripheral regions of morphospace, whereas scores of other categories often overlapped. We were also able to statistically detect the effect of relatedness with landmark data when considering the closest genetic units as a single category. A significant share of the variation in head morphology of the group can be explained by environmental variables, suggesting that conditions of the physical environment should be considered as a source of morphological variation. Future experimental work may lead to a better understanding of the roles of physical variables, plasticity and relatedness as causes underlying morphological variation.

\section{ACKNOWLEDGEMENTS}

We are deeply grateful to the two anonymous reviewers for the careful evaluation of our manuscript. We thank F. Toledo, F. Brusquetti Estrada, H. Zaher and L. Nascimento for access to specimens under their care. We are grateful to S. dos Reis and R. Clemente-Carvalho for help in learning morphometry techniques and advice in their most diverse applications; C. Espana for help in obtaining the images at the beginning of this work; S. Bogão Marques de Sousa for help with logistics; and the Instituto Chico Mendes (ICMBio) for collecting and export permits (nos. 13110-1 and 103420). Funding was provided by grants \#2005/52727-5, \#2006/56938-3, \#2007/5211362, \#2008/50928-1 and \#2013/50741-7 by São Paulo Research Foundation (FAPESP), and C.F.B.H. was supported by a fellowship from the Conselho Nacional de Desenvolvimento Científico e Tecnológico.

\section{REFERENCES}

Adams DC, Rohlf FJ, Slice DE. 2004. Geometric morphometrics: ten years of progress following the 'revolution'. Italian Journal of Zoology 71: 5-16.

Baldissera FA, Caramaschi U, Haddad CFB. 2004. Review of the Bufo crucifer species group, with descriptions of two new related species (Amphibia, Anura, Bufonidae). Arquivos do Museu Nacional 62: 255-282.

Baylac M, Friess M. 2005. Fourier descriptors, Procrustes superimposition, and data dimensionality: an example of cranial shape analysis in modern human populations. In: Slice EE, ed. Modern morphometrics in physical 
antropology. New York: Kluwer Academic/Plenum Publishers, 145-165.

Blomberg SP, Garland T Jr, Ives AR. 2003. Testing for phylogenetic signal in comparative data: behavioral traits are more labile. Evolution 57: 717-745.

Bookstein FL. 1991. Morphometric tools for landmark data: geometry and biology. Cambridge, UK: Cambridge University Press.

Bookstein FL. 1996. Biometrics, biomathematics, and the morphometrics synthesis. Bulletin of Mathematical Biology 58: $313-365$.

Bookstein FL. 1997. Landmark methods for forms without landmarks: localizing group differences in outline shape. Medical Image Analysis 1: 225-243.

Bookstein FL, Streissguth AP, Sampson PD, Connor PD, Barr HM. 2002. Corpus callosum shape and neuropsychological deficits in adult males with heavy fetal alcohol exposure. NeuroImage 15: 233-251.

Cardini A, Elton S. 2008. Does the skull carry a phylogenetic signal? Evolution and modularity in the guenons. Biological Journal of the Linnean Society 93: 813-834.

Castellano S, Giacoma C. 1998. Morphological variation of the green toad, Bufo viridis, in Italy: a test of causation. Journal of Herpetology 32: 540-550.

Castellano S, Rosso A, Doglio S, Giacoma C. 1999. Body size and calling variation in the green toad (Bufo viridis). Journal of Zoology 248: 83-90.

Clemente-Carvalho RBG, Monteiro LR, Bonato V, Rocha HS, Pereira GR, Oliveira DS, Lopes TR, Haddad CFB, Martins EG, Dos Reis SF. 2008. Geographic variation in cranial shape in the pumpkin toadlet (Brachycephalus ephippium): a geometric analysis. Journal of Herpetology 42: 176-185.

Clemente-Carvalho RBG, Alves ACR, Perez SI, Haddad CFB, Dos Reis SF. 2011. Morphological and molecular variation in the pumpkin toadlet, Brachycephalus ephippium (Anura: Brachycephalidae). Journal of Herpetology 45: 94-99.

Cole TM III, Lele SR, Richtsmeier JT. 2002. A parametric bootstrap approach to the detection of phylogenetic signal in landmark data. In: MacLeod N, Forey PL, eds. Morpholgy, shape and phylogeny. London: Taylor and Francis, 194-219.

Croix SL, Holekamp KE, Shivik JA, Lundrigan BL, Zelditch ML. 2011. Ontogenetic relationships between cranium and mandible in coyotes and hyenas. Journal of Morphology 272: 662-674.

Dryden IL, Mardia KV. 1998. Statistical shape analysis. New York: John Wiley and Sons.

Felsenstein J. 2003. Inferring phylogenies. Sunderland, MA: Sinauer Associates.

Frost DR. 2014. Amphibian species of the world: an online reference. Version 5.5 (16 March, 2011). Available at http://research.amnh.org/vz/herpetology/amphibia/. American Museum of Natural History, New York.

Goodall C. 1991. Procrustes methods in the statistical analysis of shape. Journal of the Royal Statistical Society (Series B) 53: 285-339.
Goslee SC, Urban DL. 2007. The ecodist package for dissimilarity-based analysis of ecological data. Journal of Statistical Software 22: 1-19.

Gould SJ, Johnston RF. 1972. Geographic variation. Annual Review of Ecology and Systematics 3: 457-498.

Gould SJ, Vrba ES. 1982. Expatation - a missing term in the science of form. Paleobiology 8: 4-15.

Grant PR, Grant BR. 2002. Unpredictable evolution in a 30-year study of Darwin's finches. Science 296: 707-711.

Gunz P, Mitteroecker P, Bookstein FL. 2005. Semilandmarks in three dimensions. In: Slice DE, ed. Modern morphometrics in physical anthropology. New York: Kluwer Academic/Plenum Publishers, 73-98.

Gunz P, Bookstein FL, Mitteroecker P, Stadlmayr A, Seidler H, Weber GW. 2009. Early modern human diversity suggests subdivided population structure and a complex out-of-Africa scenario. Proceedings of the National Academy of Sciences of the United States of America 106: 6094-6098.

Gvozdík V, Moravec J, Kratochvíl L. 2008. Geographic morphological variation in parapatric western Paleartic tree frog, Hyla arborea and Hyla savignyi: are related species similarly affected by climatic conditions? Biological Journal of Linnean Society 95: 539-556.

Haddad CFB, Toledo LF, Prado CPA, Loebmann D, Gasparini JL, Sazima I. 2013. Guia de anfibios da mata atlântica - diversidade e biologia. São Paulo, SP: Anolis Books.

Hijmans RJ, Cameron SE, Parra JL, Jones PG, Jarvis A. 2005. Very high resolution interpolated climate surfaces for global land areas. International Journal of Climatology 25: $1965-1978$.

Ivanović A, Sotiropoulos K, Vukov TD, Eleftherakos K, Dzukić G, Polymeni RM, Kalezić ML. 2008. Cranial shape variation and molecular phylogenetic structure of crested newts (Triturus cristatus superspecies: Caudata, Salamandridae) in the Balkans. Biological Journal of the Linnean Society 95: 348-360.

Ivanović A, Sotiropoulos K, Dzukić G, Kalezić ML. 2009. Skull size and shape variation versus molecular phylogeny: a case study of alpine newts (Mesotriton alpestris, Salamandridae) from the Balkan Peninsula. Zoomorphology 128: $157-167$.

Ivanović A, Sotiropoulos K, Uzum N, Dzukić G, Olgun K, Cogãlniceanu D, Kalezić ML. 2011. A phylogenetic view on skull and shape variation in the smooth newt ( $L i s$ sotriton vulgaris, Caudata, Salamandridae). Journal of Zoological Systematics and Revolutionary Research 50: 116124.

Keller I, Alexander JM, Holderegger R, Edwars PJ. 2013. Widespread phenotypic and genetic divergence along altitudinal gradients in animals. Journal of Evolutionary Biology 26: 2527-2543.

Klingenberg CP. 2011. MorphoJ: an integrated software package for geometric morphometrics. Molecular Ecology Resources 11: 353-357.

Klingenberg CP. 2013. Visualizations in geometric morphometrics: how to read and how to make graphs showing 
shape changes. Hystrix, The Italian Journal of Mammalogy 24: $15-24$.

Klingenberg CP, Gidaszewski NA. 2010. Testing and quantifying phylogenetic signals and homoplasy in morphometric data. Systematic Biology 59: 245-261.

Klingenberg CP, Monteiro LR. 2005. Distances and directions in multidimensional shape spaces: implications for morphometric applications. Systematic Biology 54: 678-688.

Kutrup B, Bulbul U, Yilmaz N. 2006. Effects of the ecological conditions on morphological variations of the Green toad, Bufo viridis, in Turkey. Ecological Research 21: 208-214.

Levin SA. 1992. The problem of scale in ecology. Ecology 73: 1943-1967.

Levin SA, Pacala SW. 1997. Theories of simplification and scaling of spatially distributed process. In: Tilman D, Kareiva P, eds. Space ecology: the role of space in population dynamics and interspecific interactions. Princeton, NJ: Princeton University Press, 271-295.

Lima AMX, Rodrigues RG, Bittencourt S, Condrati LH, Machado RA. 2005. Bufo henseli. First record. Herpetological Review 36: 198.

Lutz A. 1934. Notas subre especies brasileiras do genero Bufo/Zur Kenntnis der Brasilianischen Kroeten vom Genus Bufo. Memórias do Instituto Oswaldo Cruz Rio de Janeiro 28: $111-134$.

MacLeod N. 2002. Phylogenetic signal in morphometric data. In: MacLeod N, Forey PL, eds. Morpholgy, shape and phylogeny. London: Taylor and Francis, 100-138.

Maddison WP. 1991. Squared-change parsimony reconstructions of ancestral states for continuous-valued characters on a phylogenetic tree. Systematic Zoology 40: 304-314.

Marcelino VR, Haddad CFB, Alexandrino JMB. 2009. Geographic distribution and morphological variation of striped and nostriped populations of the Brazilian Atlantic forest treefrog Hypsiboas bischoffi (Anura: Hylidae). Journal of Herpetology 42: 351-361.

Martin RF. 1972. Osteology and evolution in Neotropical Bufo. American Midland Naturalist 88: 301-317.

Martins EP, Hansen TF. 1997. Phylogenies and the comparative method: a general approach to incorporating phylogenetic information into analysis of interspecific data. The American Naturalist 149:646-667.

McArdle BH, Rodrigo AG. 1994. Estimating the ancestral atates of a continuous-valued character using squaredchange parsimony: an analytical solution. Systematic Biology 43: 573-578.

Mitteroecker P, Gunz P. 2009. Advances in geometric morphometrics. Evolutionary Biology 36: 235-247.

Oxnard CE. 1978. One biologist's view of morphometrics. Annual Review of Ecology and Systematics 9: 219-241.

Paradis E, Claude J, Strimmer K. 2004. APE: analysis of phylogenetics and evolution in R. Bioinformatics 2: 289-290.

Perez SI, Bernal V, Gonzalez P. 2006. Differences between sliding semi-landmarks methods: implications for shape analyses of human populations. Journal of Anatomy 208: 769-784.

Pillar VD. 1999. The bootstrapped ordination re-examined. Journal of Vegetation Science 10: 895-902.
Polly PD, Lawing AM, Fabre A, Goswami A. 2013. Phylogenetic principal components analysis and geometric morphometrics. Hystrix, The Italian Journal of Mammalogy 24: 1-9.

Pramuk JB. 2006. Phylogeny of South American Bufo (Anura: Bufonidae) inferred from combined evidence. Zoological Journal of the Linnean Society 146: 407-452.

R Development Core Team. 2014. $R$ : a language and environment for statistical computing. Vienna: R Foundation for Statistical Computing.

Revell LJ. 2009. Size-correction and principal components for interspecific comparative studies. Evolution 63-12: 3258-3268.

Revell LJ. 2012. phytools: an $\mathrm{R}$ package for phylogenetic comparative biology (and other things). Method in Ecology and Evolution 3: 217-223.

Roberto IJ, Brito L, Thomé MTC. 2014. A new species of Rhinella (Anura: Bufonidae) from Northeastern of Brazil. South America Journal of Herpetology 9: 190-199.

Rohlf FJ. 1993. Relative warp analysis and an example of its application to mosquito wings. In: Marcus LF, GarciaValdecasas AE, eds. Contributions to morphometrics, Vol. 8. Madrid: Museo Nacional de Ciencias Naturales (CSIC), 131-159.

Rohlf FJ. 2001. Comparative methods for the analysis of continuous variables: geometric interpretations. Evolution 55: $2143-2160$.

Rohlf FJ. 2004. tps serie softwares. Available at http// life.bio.sunysb.edu/morph/.

Rohlf FJ. 2005. tpsDIG 2.10. Stony Brook, NY: SUNY. Available at: http://life.bio.sunysb.edu/morph.

Rohlf FJ, Loy A, Corti M. 1996. Morphometric analysis of Old World Talpidae (Mammalia, Insectivora) using partialwarp scores. Systematic Biology 45: 344-362.

Rosso A, Castellano S, Giacoma C. 2004. Ecogeography analysis of morphological and life-history variation in the Italian treefrog. Evolutionary Ecology 18: 303-321.

Sampson PD, Bookstein FL, Sheehan H, Bolson EL. 1996. Eigenshape analysis of left ventricular outlines from contrast ventriculograms. In: Marcus LF, Corti M, Loy A, Naylor GJP, Slice DE, eds. Advances in morphometrics, Vol. 284. Nato ASI Series, Series A: Life Science. New York: Plenum, 131-152.

Schauble C. 2004. Variation in the body size and sexual dimorphism across geographical and environmental space in the frogs Limnodynastes tasmaniensis and L. peronii. Biological Journal of the Linnean Society 82: 39-56.

Sheets HD, Keonho K, Mitchell CE. 2004. A combined landmark and outline-based approach to ontogenetic shape change in the Ordovician trilobite Triarthrus becki. In: Elewa A, ed. Applications of morphometrics in paleontology and biology. New York: Springer, 67-81.

Silveira AL, Salles ROL, Pontes RC. 2009. Primeiro registro de Rhinella pombali e novos registros de $R$. crucifer e R. ornata no Estado do Rio de Janeiro, Brasil (Amphibia, Anura, Bufonidae). Biotemas 22: 231-235.

Smouse PE, Long JC, Sokal RR. 1986. Multiple regression and correlation extensions of the Mantel test of matrix correspondence. Systematic Zoology 35: 627-632. 
Spix JB. 1824. Animalia nova sive Species novae Testudinum et Ranarum quas in itinere per Brasilian annis MDCCCXVII - MDCCCXX jussu et auspiciis Maximiliani Josephi I. Bavariae Regis. Munchen: F. S. Hubschmann.

Thomé MTC, Zamudio KR, Giovanelli JGR, Haddad CFB, Baldissera FA Jr, Alexandrino J. 2010. Phylogeography of endemic toads and post-Pliocene persistence of the Brazilian Atlantic forest. Molecular Phylogenetics and Evolution 55: 1018-1031.

Thomé MTC, Zamudio KR, Haddad CFB, Alexandrino J. 2012. Delimiting genetic units in Neotropical toads under incomplete lineage sorting and hybridization. $B M C$ Evolutionary Biology 12: 242.
Turchetto-Zolet AC, Pinheiro F, Salgueiro F, PalmaSilva C. 2013. Phylogeographical patterns shed light on evolutionary process in South America. Molecular Ecology 12: 1193-1213.

Vaz-Silva W, Valdujo PH, Pombal JP Jr. 2012. New species of the Rhinella crucifer group (Anura, Bufonidae) from the Brazilian Cerrado. Zootaxa 3265: 57-65.

Vieira KS, Arzabe C, Hernandez MIM, Vieira WLS. 2008. An examination of morphometric variations in a Neotropical toad population (Proceratophrys cristiceps, Amphibia, Anura, Cycloramphidae). PLoS ONE 3: e3934.

Wied-Neuwied MA. 1821. Reise nach Brasilien in den Jaheren 1815 bis 1817, vol. 2. Frankfurt a. M.: Henrich Ludwig Bronner.

\section{SUPPORTING INFORMATION}

Additional supporting information may be found online in the supporting information tab for this article:

Data S1. Probabilities of the regression obtained by permutation tests.

Data S2. Positioning of scores in multidimensional space represented by the first two principal components.

Data S3. Positioning of scores in multidimensional space represented by the first two phylogenetic principal components for the data set with only landmarks.

Data S4. Positioning of scores in multidimensional space represented by the first two phylogenetic principal components for the data set with only semilandmarks.

Data S5. Scores of the canonical variation and geographic origins for each specimen considered in the study.

\section{APPENDIX 1}

Representative specimens of all species of the Rhinella crucifer group analysed in this study. CFBH, 'Célio F. B. Haddad' amphibian collection; IIBPH, herpetological collection of the 'Instituto de Investigación Biológica del Paraguay'; MZUSP, Museum of Zoology University of São Paulo; MCNPUC, Museum of Natural Sciences of the Pontifícia Universidade Católica de Minas Gerais).

\begin{tabular}{llllllll}
\hline Collection no. & Species & Unit & Municipality & State/Country & Locality & Latitude & Longitude \\
\hline CFBH_118 & Rhinella ornata & C & Ubatuba & SP/BR & L1 & -23.3433861 & -45.085710 \\
CFBH_1206 & Rhinella ornata & C & Ubatuba & SP/BR & L1 & -23.3433861 & -45.085710 \\
CFBH_1208 & Rhinella ornata & C & Ubatuba & SP/BR & L1 & -23.3433861 & -45.085710 \\
CFBH_1210 & Rhinella ornata & C & Ubatuba & SP/BR & L1 & -23.3433861 & -45.085710 \\
CFBH_1216 & Rhinella ornata & C & Ubatuba & SP/BR & L1 & -23.3433861 & -45.085710 \\
CFBH_1218 & Rhinella ornata & C & Ubatuba & SP/BR & L1 & -23.3433861 & -45.085710 \\
CFBH_1219 & Rhinella ornata & C & Ubatuba & SP/BR & L1 & -23.3433861 & -45.085710 \\
CFBH_1220 & Rhinella ornata & C & Ubatuba & SP/BR & L1 & -23.3433861 & -45.085710 \\
CFBH_12545 & Rhinella ornata & C & Ubatuba & SP/BR & L1 & -23.3433861 & -45.085710 \\
CFBH_12547 & Rhinella ornata & C & Ubatuba & SP/BR & L1 & -23.3433861 & -45.085710 \\
CFBH_12549 & Rhinella ornata & C & Ubatuba & SP/BR & L1 & -23.3433861 & -45.085710 \\
CFBH_12551 & Rhinella ornata & C & Ubatuba & SP/BR & L1 & -23.3433861 & -45.085710 \\
CFBH_12552 & Rhinella ornata & C & Ubatuba & SP/BR & L1 & -23.3433861 & -45.085710 \\
CFBH_12553 & Rhinella ornata & C & Ubatuba & SP/BR & L1 & -23.3433861 & -45.085710 \\
CFBH_12554 & Rhinella ornata & C & Ubatuba & SP/BR & L1 & -23.3433861 & -45.085710 \\
CFBH_12558 & Rhinella ornata & C & Ubatuba & SP/BR & L1 & -23.3433861 & -45.085710 \\
CFBH_12559 & Rhinella ornata & C & Ubatuba & SP/BR & L1 & -23.3433861 & -45.085710 \\
CFBH_12563 & Rhinella ornata & C & Ubatuba & SP/BR & L1 & -23.3433861 & -45.085710
\end{tabular}


Appendix 1. Continued

\begin{tabular}{|c|c|c|c|c|c|c|c|}
\hline Collection no. & Species & Unit & Municipality & State/Country & Locality & Latitude & Longitude \\
\hline CFBH_12564 & Rhinella ornata & $\mathrm{C}$ & Ubatuba & SP/BR & L1 & -23.3433861 & -45.085710 \\
\hline CFBH_13361 & Rhinella crucifer & $\mathrm{N}$ & Caraíva & $\mathrm{BA} / \mathrm{BR}$ & L2 & -16.800000 & -39.150000 \\
\hline CFBH_13363 & Rhinella crucifer & $\mathrm{N}$ & Caraíva & $\mathrm{BA} / \mathrm{BR}$ & $\mathrm{L} 2$ & -16.800000 & -39.150000 \\
\hline CFBH_13364 & Rhinella crucifer & $\mathrm{N}$ & Caraíva & $\mathrm{BA} / \mathrm{BR}$ & L2 & -16.800000 & -39.150000 \\
\hline CFBH_13365 & Rhinella crucifer & $\mathrm{N}$ & Caraíva & $\mathrm{BA} / \mathrm{BR}$ & L2 & -16.800000 & -39.150000 \\
\hline CFBH_13366 & Rhinella crucifer & $\mathrm{N}$ & Caraíva & $\mathrm{BA} / \mathrm{BR}$ & L2 & -16.800000 & -39.150000 \\
\hline CFBH_13367 & Rhinella crucifer & $\mathrm{N}$ & Caraíva & $\mathrm{BA} / \mathrm{BR}$ & L2 & -16.800000 & -39.150000 \\
\hline CFBH_13368 & Rhinella crucifer & $\mathrm{N}$ & Caraíva & $\mathrm{BA} / \mathrm{BR}$ & L2 & -16.800000 & -39.150000 \\
\hline CFBH_13370 & Rhinella crucifer & $\mathrm{N}$ & Caraíva & $\mathrm{BA} / \mathrm{BR}$ & L2 & -16.800000 & -39.150000 \\
\hline CFBH_13371 & Rhinella crucifer & $\mathrm{N}$ & Caraíva & $\mathrm{BA} / \mathrm{BR}$ & L2 & -16.800000 & -39.150000 \\
\hline CFBH_13372 & Rhinella crucifer & $\mathrm{N}$ & Caraíva & $\mathrm{BA} / \mathrm{BR}$ & L2 & -16.800000 & -39.150000 \\
\hline CFBH_13374 & Rhinella crucifer & $\mathrm{N}$ & Caraíva & $\mathrm{BA} / \mathrm{BR}$ & L2 & -16.800000 & -39.150000 \\
\hline CFBH_13399 & Rhinella crucifer & $\mathrm{N}$ & Caraíva & $\mathrm{BA} / \mathrm{BR}$ & L2 & -16.800000 & -39.150000 \\
\hline CFBH_1373 & Rhinella ornata & $\mathrm{C}$ & Rio Claro & SP/BR & L3 & -22.413399 & -47.569574 \\
\hline CFBH_1377 & Rhinella crucifer & $\mathrm{H}$ & Parati & $\mathrm{RJ} / \mathrm{BR}$ & $\mathrm{L} 4$ & -23.216708 & -44.717938 \\
\hline CFBH_13938 & Rhinella ornata & $\mathrm{H}$ & Petrópolis & $\mathrm{RJ} / \mathrm{BR}$ & L5 & -22.504639 & -43.182329 \\
\hline CFBH_14647 & Putative hybrid & $\mathrm{C}$ & Cristina & MG/BR & L6 & -22.209178 & -45.271985 \\
\hline CFBH_14812 & Rhinella ornata & $\mathrm{C}$ & $\begin{array}{l}\text { São Luís do } \\
\text { Paraitinga }\end{array}$ & $\mathrm{SP} / \mathrm{BR}$ & L7 & -23.228066 & -45.322663 \\
\hline CFBH_15345 & Rhinella ornata & $\mathrm{C}$ & Ilha Bela & $\mathrm{SP} / \mathrm{BR}$ & L8 & -23.904000 & -45.335000 \\
\hline CFBH_15349 & Rhinella ornata & $\mathrm{C}$ & Ilha Bela & $\mathrm{SP} / \mathrm{BR}$ & L8 & -23.904000 & -45.335000 \\
\hline CFBH_15351 & Rhinella ornata & $\mathrm{C}$ & Ilha Bela & SP/BR & L8 & -23.904000 & -45.335000 \\
\hline CFBH_15352 & Rhinella ornata & $\mathrm{C}$ & Ilha Bela & SP/BR & L8 & -23.904000 & -45.335000 \\
\hline CFBH_15353 & Rhinella ornata & $\mathrm{C}$ & Ilha Bela & SP/BR & L8 & -23.904000 & -45.335000 \\
\hline CFBH_15354 & Rhinella ornata & $\mathrm{C}$ & Ilha Bela & SP/BR & L8 & -23.904000 & -45.335000 \\
\hline CFBH_15356 & Rhinella ornata & $\mathrm{C}$ & Ilha Bela & $\mathrm{SP} / \mathrm{BR}$ & L8 & -23.904000 & -45.335000 \\
\hline CFBH_15358 & Rhinella ornata & $\mathrm{C}$ & Ilha Bela & SP/BR & L8 & -23.904000 & -45.335000 \\
\hline CFBH_15359 & Rhinella ornata & $\mathrm{C}$ & Ilha Bela & $\mathrm{SP} / \mathrm{BR}$ & L8 & -23.904000 & -45.335000 \\
\hline CFBH_15360 & Rhinella ornata & $\mathrm{C}$ & Ilha Bela & SP/BR & L8 & -23.904000 & -45.335000 \\
\hline CFBH_15361 & Rhinella ornata & $\mathrm{C}$ & Ilha Bela & SP/BR & L8 & -23.904000 & -45.335000 \\
\hline CFBH_15362 & Rhinella ornata & $\mathrm{C}$ & Ilha Bela & SP/BR & L8 & -23.904000 & -45.335000 \\
\hline CFBH_15363 & Rhinella ornata & $\mathrm{C}$ & Ilha Bela & SP/BR & L8 & -23.904000 & -45.335000 \\
\hline CFBH_15364 & Rhinella ornata & $\mathrm{C}$ & Ilha Bela & $\mathrm{SP} / \mathrm{BR}$ & L8 & -23.904000 & -45.335000 \\
\hline CFBH_15365 & Rhinella ornata & $\mathrm{C}$ & Ilha Bela & SP/BR & L8 & -23.904000 & -45.335000 \\
\hline CFBH_15366 & Rhinella ornata & $\mathrm{C}$ & Ilha Bela & $\mathrm{SP} / \mathrm{BR}$ & L8 & -23.904000 & -45.335000 \\
\hline CFBH_15368 & Rhinella ornata & $\mathrm{C}$ & Ilha Bela & $\mathrm{SP} / \mathrm{BR}$ & L8 & -23.904000 & -45.335000 \\
\hline CFBH_15369 & Rhinella ornata & $\mathrm{C}$ & Ilha Bela & SP/BR & L8 & -23.904000 & -45.335000 \\
\hline CFBH_15379 & Rhinella ornata & $\mathrm{C}$ & Ilha Bela & SP/BR & L8 & -23.904000 & -45.335000 \\
\hline CFBH_15383 & Rhinella ornata & $\mathrm{C}$ & Ilha Bela & $\mathrm{SP} / \mathrm{BR}$ & L8 & -23.904000 & -45.335000 \\
\hline CFBH_15385 & Rhinella ornata & $\mathrm{C}$ & Ilha Bela & SP/BR & L8 & -23.904000 & -45.335000 \\
\hline CFBH_15386 & Rhinella ornata & $\mathrm{C}$ & Ilha Bela & SP/BR & L8 & -23.904000 & -45.335000 \\
\hline CFBH_15390 & Rhinella ornata & $\mathrm{C}$ & Ilha Bela & SP/BR & L8 & -23.904000 & -45.335000 \\
\hline CFBH_16310 & Rhinella ornata & $\mathrm{C}$ & $\begin{array}{l}\text { São Luís do } \\
\text { Paraitinga }\end{array}$ & SP/BR & L7 & -23.228066 & -45.322663 \\
\hline CFBH_16311 & Rhinella ornata & $\mathrm{C}$ & $\begin{array}{l}\text { São Luís do } \\
\text { Paraitinga }\end{array}$ & $\mathrm{SP} / \mathrm{BR}$ & L7 & -23.228066 & -45.322663 \\
\hline CFBH_16518 & Rhinella ornata & $\mathrm{C}$ & Ubatuba & SP/BR & $\mathrm{L} 1$ & -23.3433861 & -45.085710 \\
\hline CFBH_1683 & Rhinella ornata & $\mathrm{C}$ & Ubatuba & $\mathrm{SP} / \mathrm{BR}$ & L1 & -23.3433861 & -45.085710 \\
\hline CFBH_1689 & Rhinella ornata & $\mathrm{C}$ & Capão Bonito & $\mathrm{SP} / \mathrm{BR}$ & L9 & -24.003998 & -48.339266 \\
\hline CFBH_17400 & Rhinella ornata & $\mathrm{C}$ & Ilha Bela & SP/BR & L8 & -23.904000 & -45.335000 \\
\hline CFBH_1748 & Rhinella ornata & $\mathrm{C}$ & Ubatuba & SP/BR & L1 & -23.3433861 & -45.085710 \\
\hline CFBH_1749 & Rhinella ornata & $\mathrm{C}$ & Ubatuba & $\mathrm{SP} / \mathrm{BR}$ & L1 & -23.3433861 & -45.085710 \\
\hline CFBH_1750 & Rhinella ornata & $\mathrm{C}$ & Ubatuba & SP/BR & L1 & -23.3433861 & -45.085710 \\
\hline
\end{tabular}


Appendix 1. Continued

\begin{tabular}{|c|c|c|c|c|c|c|c|}
\hline Collection no. & Species & Unit & Municipality & State/Country & Locality & Latitude & Longitude \\
\hline CFBH_18001 & Rhinella crucifer & $\mathrm{H}$ & $\begin{array}{l}\text { Santa } \\
\text { Leopoldina }\end{array}$ & $\mathrm{ES} / \mathrm{BR}$ & L10 & -20.102515 & -40.529283 \\
\hline CFBH_18090 & Rhinella crucifer & $\mathrm{H}$ & Linhares & $\mathrm{ES} / \mathrm{BR}$ & L11 & -19.390915 & -40.071503 \\
\hline CFBH_18091 & Rhinella crucifer & $\mathrm{H}$ & Linhares & $\mathrm{ES} / \mathrm{BR}$ & L11 & -19.390915 & -40.071503 \\
\hline CFBH_18141 & Rhinella abei & $\mathrm{c} 1$ & Quatro Barras & $\mathrm{PR} / \mathrm{BR}$ & L12 & -25.367153 & -49.074947 \\
\hline CFBH_18163 & Rhinella abei & $\mathrm{c} 1$ & Blumenau & $\mathrm{SC} / \mathrm{BR}$ & L13 & -26.918996 & -49.066078 \\
\hline CFBH_18164 & Rhinella abei & $\mathrm{c} 1$ & Blumenau & $\mathrm{SC} / \mathrm{BR}$ & L13 & -26.918996 & -49.066078 \\
\hline CFBH_18166 & Rhinella abei & $\mathrm{c} 1$ & Blumenau & $\mathrm{SC} / \mathrm{BR}$ & L13 & -26.918996 & -49.066078 \\
\hline CFBH_18168 & Rhinella abei & $\mathrm{c} 1$ & Blumenau & $\mathrm{SC} / \mathrm{BR}$ & L13 & -26.918996 & -49.066078 \\
\hline CFBH_18169 & Rhinella abei & $\mathrm{c} 1$ & Blumenau & $\mathrm{SC} / \mathrm{BR}$ & L13 & -26.918996 & -49.066078 \\
\hline CFBH_18175 & Rhinella abei & $\mathrm{c} 1$ & Massaranduba & $\mathrm{SC} / \mathrm{BR}$ & L14 & -26.610913 & -49.009150 \\
\hline CFBH_18176 & Rhinella abei & $\mathrm{c} 1$ & Massaranduba & $\mathrm{SC} / \mathrm{BR}$ & L14 & -26.610913 & -49.009150 \\
\hline CFBH_18177 & Rhinella abei & $\mathrm{c} 1$ & Massaranduba & $\mathrm{SC} / \mathrm{BR}$ & L14 & -26.610913 & -49.009150 \\
\hline CFBH_18178 & Rhinella abei & $\mathrm{c} 1$ & Massaranduba & $\mathrm{SC} / \mathrm{BR}$ & L14 & -26.610913 & -49.009150 \\
\hline CFBH_18179 & Rhinella abei & $\mathrm{c} 1$ & Massaranduba & $\mathrm{SC} / \mathrm{BR}$ & L14 & -26.610913 & -49.009150 \\
\hline CFBH_18180 & Rhinella abei & $\mathrm{c} 1$ & Massaranduba & $\mathrm{SC} / \mathrm{BR}$ & L14 & -26.610913 & -49.009150 \\
\hline CFBH_18181 & Rhinella abei & $\mathrm{c} 1$ & Massaranduba & $\mathrm{SC} / \mathrm{BR}$ & L14 & -26.610913 & -49.009150 \\
\hline CFBH_18182 & Rhinella abei & $\mathrm{c} 1$ & Massaranduba & $\mathrm{SC} / \mathrm{BR}$ & L14 & -26.610913 & -49.009150 \\
\hline CFBH_18238 & Rhinella henseli & $\mathrm{S}$ & Bento Goncalves & $\mathrm{RS} / \mathrm{BR}$ & L15 & -29.096543 & -51.451038 \\
\hline CFBH_18382 & Rhinella ornata & $\mathrm{C}$ & Teodoro Sampaio & $\mathrm{SP} / \mathrm{BR}$ & L16 & -22.531624 & -52.183277 \\
\hline CFBH_18387 & Rhinella ornata & $\mathrm{C}$ & Teodoro Sampaio & $\mathrm{SP} / \mathrm{BR}$ & L16 & -22.531624 & -52.183277 \\
\hline CFBH_18717 & Rhinella crucifer & $\mathrm{N}$ & Aurelino Leal & $\mathrm{BA} / \mathrm{BR}$ & L17 & -14.360787 & -39.408552 \\
\hline CFBH_18815 & Rhinella crucifer & $\mathrm{H}$ & Teresópolis & $\mathrm{RJ} / \mathrm{BR}$ & L18 & -22.412324 & -42.966432 \\
\hline CFBH_18816 & Rhinella crucifer & $\mathrm{H}$ & Teresópolis & $\mathrm{RJ} / \mathrm{BR}$ & L18 & -22.412324 & -42.966432 \\
\hline CFBH_20277 & Rhinella henseli & $\mathrm{S}$ & Anitápolis & $\mathrm{SC} / \mathrm{BR}$ & L19 & -27.902458 & -49.129065 \\
\hline CFBH_20278 & Rhinella henseli & $\mathrm{S}$ & Anitápolis & $\mathrm{SC} / \mathrm{BR}$ & L19 & -27.902458 & -49.129065 \\
\hline CFBH_20279 & Rhinella henseli & $\mathrm{S}$ & Anitápolis & $\mathrm{SC} / \mathrm{BR}$ & L19 & -27.902458 & -49.129065 \\
\hline CFBH_20280 & Rhinella henseli & $\mathrm{S}$ & Anitápolis & $\mathrm{SC} / \mathrm{BR}$ & L19 & -27.902458 & -49.129065 \\
\hline CFBH_20281 & Rhinella henseli & $\mathrm{S}$ & Anitápolis & $\mathrm{SC} / \mathrm{BR}$ & L19 & -27.902458 & -49.129065 \\
\hline CFBH_20282 & Rhinella abei & $\mathrm{c} 1$ & Anitápolis & $\mathrm{SC} / \mathrm{BR}$ & L19 & -27.902458 & -49.129065 \\
\hline CFBH_20283 & Rhinella abei & $\mathrm{C}$ & Anitápolis & $\mathrm{SC} / \mathrm{BR}$ & L19 & -27.902458 & -49.129065 \\
\hline CFBH_20284 & Rhinella abei & $\mathrm{c} 1$ & Anitápolis & $\mathrm{SC} / \mathrm{BR}$ & L19 & -27.902458 & -49.129065 \\
\hline CFBH_21056 & Rhinella crucifer & $\mathrm{N}$ & Urucuca & $\mathrm{BA} / \mathrm{BR}$ & L20 & -14.586809 & -39.291382 \\
\hline CFBH_21058 & Rhinella crucifer & $\mathrm{N}$ & Urucuca & $\mathrm{BA} / \mathrm{BR}$ & L20 & -14.586809 & -39.291382 \\
\hline CFBH_21113 & Rhinella crucifer & $\mathrm{N}$ & Urucuca & $\mathrm{BA} / \mathrm{BR}$ & L20 & -14.586809 & -39.291382 \\
\hline CFBH_21230 & Rhinella henseli & $\mathrm{S}$ & Florianópolis & $\mathrm{SC} / \mathrm{BR}$ & L21 & -27.597024 & -48.549583 \\
\hline CFBH_21317 & Rhinella abei & $\mathrm{c} 1$ & Guaratuba & $\mathrm{SC} / \mathrm{BR}$ & L22 & -25.883413 & -48.576213 \\
\hline CFBH_22659 & Rhinella abei & $\mathrm{c} 1$ & $\begin{array}{l}\text { Governador } \\
\text { Celso Ramos }\end{array}$ & $\mathrm{SC} / \mathrm{BR}$ & L23 & -27.315793 & -48.558841 \\
\hline CFBH_22816 & Putative hybrid & $\mathrm{H}$ & Belo Horizonte & MG/BR & L24 & -19.815731 & -43.954223 \\
\hline CFBH_22897 & Rhinella abei & $\mathrm{c} 1$ & Morretes & $\mathrm{PR} / \mathrm{BR}$ & L25 & -25.476311 & -48.835779 \\
\hline CFBH_23165 & Rhinella abei & $\mathrm{c} 1$ & Morretes & $\mathrm{PR} / \mathrm{BR}$ & L25 & -25.476311 & -48.835779 \\
\hline CFBH_23166 & Rhinella abei & $\mathrm{c} 1$ & Morretes & PR/BR & L25 & -25.476311 & -48.835779 \\
\hline CFBH_23210 & Rhinella crucifer & $\mathrm{H}$ & Vitória & $\mathrm{ES} / \mathrm{BR}$ & L26 & -20.322186 & -40.338089 \\
\hline CFBH_23211 & Rhinella crucifer & $\mathrm{H}$ & $\begin{array}{r}\text { Conceicão } \\
\text { da Barra }\end{array}$ & $\mathrm{ES} / \mathrm{BR}$ & L27 & -18.592569 & -39.734653 \\
\hline CFBH_23368 & Rhinella crucifer & $\mathrm{N}$ & Urucuca & $\mathrm{BA} / \mathrm{BR}$ & L20 & -14.586809 & -39.291382 \\
\hline CFBH_23404 & Rhinella crucifer & $\mathrm{N}$ & João Pessoa & $\mathrm{PB} / \mathrm{BR}$ & L28 & -7.115320 & -34.861051 \\
\hline CFBH_23728 & Rhinella abei & $\mathrm{c} 1$ & Siderópolis & $\mathrm{SC} / \mathrm{BR}$ & L29 & -28.598892 & -49.425409 \\
\hline CFBH_23729 & Rhinella abei & $\mathrm{c} 1$ & Siderópolis & $\mathrm{SC} / \mathrm{BR}$ & L29 & -28.598892 & -49.425409 \\
\hline CFBH_23919 & Rhinella ornata & $\mathrm{C}$ & Santos & $\mathrm{SP} / \mathrm{BR}$ & L30 & -23.961836 & -46.332247 \\
\hline CFBH_2427 & Rhinella crucifer & $\mathrm{H}$ & $\begin{array}{r}\text { Conceicão } \\
\text { da Barra }\end{array}$ & $\mathrm{ES} / \mathrm{BR}$ & L27 & -18.592569 & -39.734653 \\
\hline
\end{tabular}


Appendix 1. Continued

\begin{tabular}{|c|c|c|c|c|c|c|c|}
\hline Collection no. & Species & Unit & Municipality & State/Country & Locality & Latitude & Longitude \\
\hline CFBH_24271 & Rhinella ornata & $\mathrm{C}$ & Derrubadas & $\mathrm{RS} / \mathrm{BR}$ & L31 & -27.265601 & -53.861366 \\
\hline CFBH_24628 & Rhinella crucifer & $\mathrm{N}$ & Camacan & $\mathrm{BA} / \mathrm{BR}$ & L32 & -15.414307 & -39.500992 \\
\hline CFBH_24629 & Rhinella crucifer & $\mathrm{N}$ & Camacan & $\mathrm{BA} / \mathrm{BR}$ & L32 & -15.414307 & -39.500992 \\
\hline CFBH_24630 & Rhinella crucifer & $\mathrm{N}$ & Camacan & $\mathrm{BA} / \mathrm{BR}$ & L32 & -15.414307 & -39.500992 \\
\hline CFBH_2583 & Rhinella crucifer & $\mathrm{N}$ & Ilhéus & $\mathrm{BA} / \mathrm{BR}$ & L33 & -14.729 & -39.079 \\
\hline CFBH_27907 & Rhinella crucifer & $\mathrm{N}$ & Palmeiras & $\mathrm{BA} / \mathrm{BR}$ & L34 & -12.529909 & -41.575086 \\
\hline CFBH_27996 & Rhinella crucifer & $\mathrm{N}$ & Santa Bárbara & $\mathrm{BA} / \mathrm{BR}$ & L35 & -11.957935 & -38.967849 \\
\hline CFBH_28097 & Rhinella crucifer & $\mathrm{H}$ & $\begin{array}{c}\text { Santa Maria } \\
\text { Madalena }\end{array}$ & $\mathrm{RJ} / \mathrm{BR}$ & L36 & -21.970085 & -41.999240 \\
\hline CFBH_28098 & Rhinella crucifer & $\mathrm{H}$ & $\begin{array}{c}\text { Santa Maria } \\
\text { Madalena }\end{array}$ & $\mathrm{RJ} / \mathrm{BR}$ & L36 & -21.970085 & -41.999240 \\
\hline CFBH_28099 & Rhinella crucifer & $\mathrm{H}$ & $\begin{array}{c}\text { Santa Maria } \\
\text { Madalena }\end{array}$ & $\mathrm{RJ} / \mathrm{BR}$ & L36 & -21.970085 & -41.999240 \\
\hline CFBH_28100 & Rhinella crucifer & $\mathrm{H}$ & $\begin{array}{c}\text { Santa Maria } \\
\text { Madalena }\end{array}$ & $\mathrm{RJ} / \mathrm{BR}$ & L36 & -21.970085 & -41.999240 \\
\hline CFBH_28170 & Rhinella casconi & $\mathrm{G}$ & Guaramiranga & $\mathrm{CE} / \mathrm{BR}$ & L37 & -4.271387 & -38.946244 \\
\hline CFBH_28171 & Rhinella casconi & $\mathrm{G}$ & Guaramiranga & $\mathrm{CE} / \mathrm{BR}$ & L37 & -4.271387 & -38.946244 \\
\hline CFBH_28172 & Rhinella casconi & $\mathrm{G}$ & Guaramiranga & $\mathrm{CE} / \mathrm{BR}$ & L37 & -4.271387 & -38.946244 \\
\hline CFBH_28174 & Rhinella casconi & $\mathrm{G}$ & Guaramiranga & $\mathrm{CE} / \mathrm{BR}$ & L37 & -4.271387 & -38.946244 \\
\hline CFBH_28175 & Rhinella casconi & $\mathrm{G}$ & Guaramiranga & $\mathrm{CE} / \mathrm{BR}$ & L37 & -4.271387 & -38.946244 \\
\hline CFBH_2834 & Rhinella crucifer & $\mathrm{H}$ & Aracruz & $\mathrm{ES} / \mathrm{BR}$ & L38 & -19.819578 & -40.274341 \\
\hline CFBH_2837 & Rhinella abei & $\mathrm{c} 1$ & Morretes & $\mathrm{PR} / \mathrm{BR}$ & L25 & -25.476311 & -48.835779 \\
\hline CFBH_2841 & Rhinella abei & $\mathrm{c} 1$ & Itapoá & $\mathrm{SC} / \mathrm{BR}$ & L39 & -26.117364 & -48.616764 \\
\hline CFBH_2842 & Rhinella abei & $\mathrm{c} 1$ & Rio dos Cedros & $\mathrm{SC} / \mathrm{BR}$ & L40 & -26.738244 & -49.272623 \\
\hline CFBH_2843 & Rhinella abei & $\mathrm{c} 1$ & Rio dos Cedros & $\mathrm{SC} / \mathrm{BR}$ & L40 & -26.738244 & -49.272623 \\
\hline CFBH_2844 & Rhinella abei & $\mathrm{c} 1$ & Rio dos Cedros & $\mathrm{SC} / \mathrm{BR}$ & $\mathrm{L} 40$ & -26.738244 & -49.272623 \\
\hline CFBH_2858 & Rhinella abei & $\mathrm{c} 1$ & Blumenau & $\mathrm{SC} / \mathrm{BR}$ & L13 & -26.918996 & -49.066078 \\
\hline CFBH_2865 & Rhinella crucifer & $\mathrm{H}$ & Aracruz & $\mathrm{ES} / \mathrm{BR}$ & L38 & -19.819578 & -40.274341 \\
\hline CFBH_2866 & Rhinella crucifer & $\mathrm{H}$ & Aracruz & $\mathrm{ES} / \mathrm{BR}$ & L38 & -19.819578 & -40.274341 \\
\hline CFBH_2867 & Rhinella crucifer & $\mathrm{H}$ & Aracruz & $\mathrm{ES} / \mathrm{BR}$ & L38 & -19.819578 & -40.274341 \\
\hline CFBH_2869 & Rhinella crucifer & $\mathrm{H}$ & Itaguaí & $\mathrm{RJ} / \mathrm{BR}$ & L41 & -22.866539 & -43.777224 \\
\hline CFBH_2870 & Rhinella crucifer & $\mathrm{H}$ & Itaguaí & $\mathrm{RJ} / \mathrm{BR}$ & L41 & -22.866539 & -43.777224 \\
\hline CFBH_2871 & Rhinella crucifer & $\mathrm{H}$ & Itaguaí & $\mathrm{RJ} / \mathrm{BR}$ & L41 & -22.866539 & -43.777224 \\
\hline CFBH_2874 & Rhinella crucifer & $\mathrm{H}$ & Vila Velha & $\mathrm{ES} / \mathrm{BR}$ & L42 & -20.330467 & -40.292161 \\
\hline CFBH_2875 & Rhinella crucifer & $\mathrm{H}$ & Vila Velha & $\mathrm{ES} / \mathrm{BR}$ & L42 & -20.330467 & -40.292161 \\
\hline CFBH_2876 & Rhinella crucifer & $\mathrm{H}$ & Vila Velha & $\mathrm{ES} / \mathrm{BR}$ & $\mathrm{L} 42$ & -20.330467 & -40.292161 \\
\hline CFBH_2877 & Rhinella crucifer & $\mathrm{H}$ & Vila Velha & $\mathrm{ES} / \mathrm{BR}$ & $\mathrm{L} 42$ & -20.330467 & -40.292161 \\
\hline CFBH_2898 & Rhinella crucifer & $\mathrm{N}$ & Ilhéus & $\mathrm{BA} / \mathrm{BR}$ & L33 & -14.729 & -39.079 \\
\hline CFBH_2901 & Rhinella crucifer & $\mathrm{N}$ & Ilhéus & $\mathrm{BA} / \mathrm{BR}$ & L33 & -14.729 & -39.079 \\
\hline CFBH_2903 & Rhinella crucifer & $\mathrm{N}$ & Ilhéus & $\mathrm{BA} / \mathrm{BR}$ & L33 & -14.729 & -39.079 \\
\hline CFBH_2904 & Rhinella crucifer & $\mathrm{N}$ & Ilhéus & $\mathrm{BA} / \mathrm{BR}$ & L33 & -14.729 & -39.079 \\
\hline CFBH_2907 & Rhinella ornata & $\mathrm{C}$ & Ubatuba & $\mathrm{SP} / \mathrm{BR}$ & L1 & -23.3433861 & -45.085710 \\
\hline CFBH_2908 & Rhinella ornata & $\mathrm{C}$ & Ubatuba & $\mathrm{SP} / \mathrm{BR}$ & $\mathrm{L} 1$ & -23.3433861 & -45.085710 \\
\hline CFBH_2909 & Rhinella ornata & $\mathrm{C}$ & Ubatuba & $\mathrm{SP} / \mathrm{BR}$ & L1 & -23.3433861 & -45.085710 \\
\hline CFBH_2916 & Rhinella abei & $\mathrm{c} 1$ & Guaratuba & $\mathrm{SC} / \mathrm{BR}$ & L22 & -25.883413 & -48.576213 \\
\hline CFBH_2918 & Rhinella abei & $\mathrm{c} 1$ & Guaratuba & $\mathrm{SC} / \mathrm{BR}$ & L22 & -25.883413 & -48.576213 \\
\hline CFBH_326 & Rhinella ornata & $\mathrm{C}$ & Ubatuba & SP/BR & $\mathrm{L} 1$ & -23.3433861 & -45.085710 \\
\hline CFBH_327 & Rhinella ornata & $\mathrm{C}$ & Ubatuba & $\mathrm{SP} / \mathrm{BR}$ & L1 & -23.3433861 & -45.085710 \\
\hline CFBH_328 & Rhinella ornata & $\mathrm{C}$ & Ubatuba & $\mathrm{SP} / \mathrm{BR}$ & L1 & -23.3433861 & -45.085710 \\
\hline CFBH_329 & Rhinella ornata & $\mathrm{C}$ & Ubatuba & SP/BR & L1 & -23.3433861 & -45.085710 \\
\hline CFBH_3727 & Rhinella ornata & $\mathrm{C}$ & Caraguatatuba & $\mathrm{SP} / \mathrm{BR}$ & $\mathrm{L} 43$ & -23.622528 & -45.411901 \\
\hline CFBH_4177 & Rhinella crucifer & $\mathrm{H}$ & Santa Teresa & $\mathrm{ES} / \mathrm{BR}$ & $\mathrm{L} 44$ & -19.931464 & -40.595243 \\
\hline CFBH_5066 & Rhinella ornata & $\mathrm{H}$ & Parati & $\mathrm{RJ} / \mathrm{BR}$ & $\mathrm{L} 4$ & -23.216708 & -44.717938 \\
\hline
\end{tabular}


Appendix 1. Continued

\begin{tabular}{|c|c|c|c|c|c|c|c|}
\hline Collection no. & Species & Unit & Municipality & State/Country & Locality & Latitude & Longitude \\
\hline CFBH_5081 & Rhinella ornata & $\mathrm{C}$ & Rio Claro & SP/BR & L3 & -22.413399 & -47.569574 \\
\hline CFBH_5082 & Rhinella ornata & $\mathrm{C}$ & Rio Claro & SP/BR & L3 & -22.413399 & -47.569574 \\
\hline CFBH_5083 & Rhinella ornata & $\mathrm{C}$ & Rio Claro & SP/BR & L3 & -22.413399 & -47.569574 \\
\hline CFBH_5786 & Rhinella crucifer & $\mathrm{H}$ & Parati & $\mathrm{RJ} / \mathrm{BR}$ & $\mathrm{L} 4$ & -23.216708 & -44.717938 \\
\hline CFBH_6336 & Rhinella ornata & $\mathrm{C}$ & Iporanga & $\mathrm{SP} / \mathrm{BR}$ & $\mathrm{L} 45$ & -23.439164 & -47.424532 \\
\hline CFBH_6364 & Rhinella ornata & $\mathrm{C}$ & Cananéia & SP/BR & L46 & -25.024353 & -47.932267 \\
\hline CFBH_6366 & Rhinella ornata & $\mathrm{C}$ & Cananéia & $\mathrm{SP} / \mathrm{BR}$ & L46 & -25.024353 & -47.932267 \\
\hline CFBH_6368 & Rhinella ornata & $\mathrm{C}$ & Cananéia & SP/BR & L46 & -25.024353 & -47.932267 \\
\hline CFBH_6369 & Rhinella ornata & $\mathrm{C}$ & Cananéia & SP/BR & L46 & -25.024353 & -47.932267 \\
\hline CFBH_6371 & Rhinella ornata & $\mathrm{C}$ & Barra do Turvo & $\mathrm{SP} / \mathrm{BR}$ & $\mathrm{L} 47$ & -24.757996 & -48.504925 \\
\hline CFBH_6372 & Rhinella ornata & $\mathrm{C}$ & Barra do Turvo & SP/BR & L47 & -24.757996 & -48.504925 \\
\hline CFBH_6902 & Rhinella ornata & $\mathrm{C}$ & Ribeirão Branco & $\mathrm{SP} / \mathrm{BR}$ & L48 & -24.219601 & -48.767826 \\
\hline CFBH_6903 & Rhinella ornata & $\mathrm{C}$ & Ribeirão Branco & SP/BR & $\mathrm{L} 48$ & -24.219601 & -48.767826 \\
\hline CFBH_7193 & Rhinella ornata & $\mathrm{C}$ & $\begin{array}{l}\text { Santo Antônio } \\
\text { dos Pinhais }\end{array}$ & $\mathrm{SP} / \mathrm{BR}$ & L49 & -22.825353 & -45.663319 \\
\hline CFBH_7194 & Rhinella ornata & $\mathrm{C}$ & $\begin{array}{c}\text { Santo Antônio } \\
\text { dos Pinhais }\end{array}$ & $\mathrm{SP} / \mathrm{BR}$ & L49 & -22.825353 & -45.663319 \\
\hline CFBH_725 & Rhinella ornata & $\mathrm{C}$ & Jundiaí & SP/BR & L50 & -23.186453 & -46.884453 \\
\hline CFBH_726 & Rhinella ornata & $\mathrm{C}$ & Jundiaí & SP/BR & L50 & -23.186453 & -46.884453 \\
\hline CFBH_727 & Rhinella ornata & $\mathrm{C}$ & Jundiaí & SP/BR & L50 & -23.186453 & -46.884453 \\
\hline CFBH_7566 & Rhinella henseli & $\mathrm{S}$ & $\begin{array}{l}\text { São João do } \\
\text { Triunfo }\end{array}$ & $\mathrm{SC} / \mathrm{BR}$ & L51 & -25.620462 & -50.486946 \\
\hline CFBH_7665 & Rhinella ornata & $\mathrm{C}$ & São Sebastião & $\mathrm{SP} / \mathrm{BR}$ & L52 & -23.761044 & -45.412088 \\
\hline CFBH_7666 & Rhinella ornata & $\mathrm{C}$ & São Sebastião & SP/BR & L52 & -23.761044 & -45.412088 \\
\hline CFBH_7753 & Rhinella ornata & $\mathrm{C}$ & Ilha Bela & SP/BR & L8 & -23.904000 & -45.335000 \\
\hline CFBH_7754 & Rhinella ornata & $\mathrm{C}$ & Ilha Bela & SP/BR & L8 & -23.904000 & -45.335000 \\
\hline CFBH_7755 & Rhinella ornata & $\mathrm{C}$ & Ilha Bela & $\mathrm{SP} / \mathrm{BR}$ & L8 & -23.904000 & -45.335000 \\
\hline CFBH_8353 & Rhinella ornata & $\mathrm{C}$ & Rio Claro & SP/BR & L3 & -22.413399 & -47.569574 \\
\hline CFBH_8354 & Rhinella ornata & $\mathrm{C}$ & Rio Claro & SP/BR & L3 & -22.413399 & -47.569574 \\
\hline CFBH_8355 & Rhinella ornata & $\mathrm{C}$ & Rio Claro & SP/BR & L3 & -22.413399 & -47.569574 \\
\hline CFBH_8358 & Rhinella ornata & $\mathrm{C}$ & Rio Claro & SP/BR & L3 & -22.413399 & -47.569574 \\
\hline CFBH_8359 & Rhinella ornata & $\mathrm{C}$ & Rio Claro & SP/BR & L3 & -22.413399 & -47.569574 \\
\hline CFBH_8360 & Rhinella ornata & $\mathrm{C}$ & Rio Claro & SP/BR & L3 & -22.413399 & -47.569574 \\
\hline CFBH_8458 & Rhinella abei & $\mathrm{c} 1$ & Itapema & $\mathrm{SC} / \mathrm{BR}$ & L53 & -27.090960 & -48.611995 \\
\hline CFBH_8911 & Rhinella ornata & $\mathrm{C}$ & $\begin{array}{l}\text { São Luís } \\
\text { do Paraitinga }\end{array}$ & $\mathrm{SP} / \mathrm{BR}$ & L7 & -23.228066 & -45.322663 \\
\hline CFBH_958 & Rhinella crucifer & $\mathrm{H}$ & Linhares & $\mathrm{ES} / \mathrm{BR}$ & L11 & -19.390915 & -40.071503 \\
\hline CFBH_959 & Rhinella crucifer & $\mathrm{H}$ & Linhares & $\mathrm{ES} / \mathrm{BR}$ & L11 & -19.390915 & -40.071503 \\
\hline CFBH_9851 & Rhinella abei & $\mathrm{c} 1$ & Treviso & $\mathrm{SC} / \mathrm{BR}$ & L54 & -28.513920 & -49.457338 \\
\hline CFBH_9937 & Putative hybrid & $\mathrm{C}$ & Cristina & MG/BR & $\mathrm{L} 6$ & -22.209178 & -45.271985 \\
\hline CFBH_9965 & Rhinella henseli & $\mathrm{S}$ & Anitápolis & $\mathrm{SC} / \mathrm{BR}$ & L19 & -27.902458 & -49.129065 \\
\hline CFBH_9966 & Rhinella abei & $\mathrm{c} 1$ & Anitápolis & $\mathrm{SC} / \mathrm{BR}$ & L19 & -27.902458 & -49.129065 \\
\hline IIBPH_1191 & Rhinella ornata & $\mathrm{C}$ & Itapúa & IT/PAR & L55 & -26.565580 & -55.683650 \\
\hline IIBPH_1333 & Rhinella ornata & $\mathrm{C}$ & Canindeyú & $\mathrm{CA} / \mathrm{PAR}$ & L56 & -24.137960 & -55.668190 \\
\hline IIBPH_1342 & Rhinella ornata & $\mathrm{C}$ & Itapúa & IT/PAR & L55 & -26.565580 & -55.683650 \\
\hline IIBPH_1563 & Rhinella ornata & $\mathrm{C}$ & Itapúa & IT/PAR & L55 & -24.137960 & -55.668190 \\
\hline IIBPH_1564 & Rhinella ornata & $\mathrm{C}$ & Itapúa & IT/PAR & L55 & -24.137960 & -55.668190 \\
\hline IIBPH_1565 & Rhinella ornata & $\mathrm{C}$ & Itapúa & IT/PAR & L55 & -24.137960 & -55.668190 \\
\hline IIBPH_1566 & Rhinella ornata & $\mathrm{C}$ & Itapúa & IT/PAR & L55 & -26.565580 & -55.683650 \\
\hline IIBPH_1567 & Rhinella ornata & $\mathrm{C}$ & Itapúa & IT/PAR & L55 & -24.137960 & -55.668190 \\
\hline MZUSP_142100 & Rhinella inopina & $\mathrm{P}$ & Januária & MG/BR & L57 & -15.495640 & -44.362592 \\
\hline MZUSP_142101 & Rhinella inopina & $\mathrm{P}$ & Januária & $\mathrm{MG} / \mathrm{BR}$ & L57 & -15.495640 & -44.362592 \\
\hline MZUSP_142105 & Rhinella inopina & $\mathrm{P}$ & Januária & MG/BR & L57 & -15.495640 & -44.362592 \\
\hline
\end{tabular}


Appendix 1. Continued

\begin{tabular}{|c|c|c|c|c|c|c|c|}
\hline Collection no. & Species & Unit & Municipality & State/Country & Locality & Latitude & Longitude \\
\hline MZUSP_142362 & Rhinella inopina & $\mathrm{P}$ & Januária & MG/BR & L57 & -15.495640 & -44.362592 \\
\hline PUC_11666 & Putative hybrid & $\mathrm{H}$ & Lima Duarte & MG/BR & L58 & -21.848352 & -43.807533 \\
\hline PUC_11667 & Putative hybrid & $\mathrm{H}$ & Lima Duarte & MG/BR & L58 & -21.848352 & -43.807533 \\
\hline PUC_11671 & Putative hybrid & $\mathrm{H}$ & Caeté & MG/BR & L59 & -19.880666 & -43.669804 \\
\hline PUC_11707 & Putative hybrid & $\mathrm{H}$ & $\begin{array}{l}\text { São Goncalo } \\
\text { do Rio Preto }\end{array}$ & $\mathrm{MG} / \mathrm{BR}$ & L60 & -18.006592 & -43.395201 \\
\hline PUC_11911 & Putative hybrid & $\mathrm{H}$ & $\begin{array}{l}\text { São Goncalo } \\
\text { do Rio Abaixo }\end{array}$ & MG/BR & L61 & -19.828069 & -43.381984 \\
\hline PUC_11940 & Putative hybrid & $\mathrm{H}$ & Nova Lima & MG/BR & L62 & -19.987594 & -43.846311 \\
\hline PUC_11941 & Putative hybrid & $\mathrm{H}$ & Nova Lima & MG/BR & L62 & -19.987594 & -43.846311 \\
\hline PUC_11942 & Putative hybrid & $\mathrm{H}$ & Nova Lima & MG/BR & L62 & -19.987594 & -43.846311 \\
\hline PUC_11943 & Putative hybrid & $\mathrm{H}$ & Nova Lima & MG/BR & L62 & -19.987594 & -43.846311 \\
\hline PUC_11944 & Putative hybrid & $\mathrm{H}$ & Nova Lima & MG/BR & L62 & -19.987594 & -43.846311 \\
\hline PUC_12035 & Putative hybrid & $\mathrm{H}$ & Rio Piracicaba & MG/BR & L63 & -19.926313 & -43.169470 \\
\hline PUC_12565 & Putative hybrid & $\mathrm{H}$ & Mar de Espanha & MG/BR & L64 & -21.868582 & -43.009314 \\
\hline PUC_1384 & Putative hybrid & $\mathrm{H}$ & Joanésia & MG/BR & L65 & -19.171585 & -42.680580 \\
\hline PUC_1914 & Putative hybrid & $\mathrm{H}$ & $\begin{array}{l}\text { São Goncalo } \\
\text { do Rio Abaixo }\end{array}$ & MG/BR & L61 & -19.828069 & -43.381984 \\
\hline PUC_1966 & Putative hybrid & $\mathrm{H}$ & Serra do Caraca & MG/BR & L66 & -20.133333 & -43.500000 \\
\hline PUC_2841 & Putative hybrid & $\mathrm{H}$ & Cariacica & $\mathrm{ES} / \mathrm{BR}$ & L67 & -20.265519 & -40.420328 \\
\hline PUC_2842 & Putative hybrid & $\mathrm{H}$ & Cariacica & $\mathrm{ES} / \mathrm{BR}$ & L67 & -20.265519 & -40.420328 \\
\hline PUC_3150 & Putative hybrid & $\mathrm{H}$ & Brumadinho & MG/BR & L68 & -20.118182 & -44.200950 \\
\hline PUC_3525 & Putative hybrid & $\mathrm{H}$ & Belo Horizonte & MG/BR & L24 & -19.815731 & -43.954223 \\
\hline PUC_3526 & Putative hybrid & $\mathrm{H}$ & Belo Horizonte & MG/BR & L24 & -19.815731 & -43.954223 \\
\hline PUC_3527 & Putative hybrid & $\mathrm{H}$ & Belo Horizonte & MG/BR & L24 & -19.815731 & -43.954223 \\
\hline PUC_3528 & Putative hybrid & $\mathrm{H}$ & Belo Horizonte & MG/BR & L24 & -19.815731 & -43.954223 \\
\hline PUC_3530 & Putative hybrid & $\mathrm{H}$ & Belo Horizonte & MG/BR & L24 & -19.815731 & -43.954223 \\
\hline PUC_3534 & Putative hybrid & $\mathrm{H}$ & Belo Horizonte & MG/BR & $\mathrm{L} 24$ & -19.815731 & -43.954223 \\
\hline PUC_3538 & Putative hybrid & $\mathrm{H}$ & Belo Horizonte & MG/BR & L24 & -19.815731 & -43.954223 \\
\hline PUC_4023 & Putative hybrid & $\mathrm{N}$ & $\begin{array}{l}\text { Santa Maria } \\
\text { do Salto }\end{array}$ & MG/BR & L69 & -16.234376 & -40.145041 \\
\hline PUC_4024 & Putative hybrid & $\mathrm{N}$ & $\begin{array}{l}\text { Santa Maria } \\
\text { do Salto }\end{array}$ & MG/BR & L69 & -16.234376 & -40.145041 \\
\hline PUC_4977 & Putative hybrid & $\mathrm{H}$ & $\begin{array}{l}\text { Conceicão do } \\
\text { Mato Dentro }\end{array}$ & $\mathrm{MG} / \mathrm{BR}$ & L70 & -19.042033 & -43.417678 \\
\hline PUC_5143 & Putative hybrid & $\mathrm{H}$ & Belo Horizonte & MG/BR & L24 & -19.815731 & -43.954223 \\
\hline PUC_5144 & Putative hybrid & $\mathrm{H}$ & Belo Horizonte & MG/BR & L24 & -19.815731 & -43.954223 \\
\hline PUC_5176 & Putative hybrid & $\mathrm{H}$ & Belo Horizonte & MG/BR & L24 & -19.815731 & -43.954223 \\
\hline PUC_5572 & Putative hybrid & $\mathrm{H}$ & Belo Horizonte & MG/BR & L24 & -19.815731 & -43.954223 \\
\hline PUC_5693 & Putative hybrid & $\mathrm{H}$ & Varginha & MG/BR & L71 & -21.546379 & -45.430813 \\
\hline PUC_5694 & Putative hybrid & $\mathrm{H}$ & Varginha & MG/BR & L71 & -21.546379 & -45.430813 \\
\hline PUC_6003 & Putative hybrid & $\mathrm{H}$ & Belo Horizonte & MG/BR & L24 & -19.815731 & -43.954223 \\
\hline PUC_6064 & Putative hybrid & $\mathrm{H}$ & Juíz de Fora & MG/BR & L72 & -21.764210 & -43.349570 \\
\hline PUC_6178 & Putative hybrid & $\mathrm{N}$ & $\begin{array}{l}\text { Santa Maria } \\
\text { do Salto }\end{array}$ & MG/BR & L69 & -16.234376 & -40.145041 \\
\hline PUC_6947 & Putative hybrid & $\mathrm{H}$ & $\begin{array}{l}\text { Conselheiro } \\
\text { Lafaiete }\end{array}$ & $\mathrm{MG} / \mathrm{BR}$ & L73 & -20.659660 & -43.785501 \\
\hline PUC_6959 & Putative hybrid & $\mathrm{H}$ & Ouro Branco & MG/BR & L74 & -20.517088 & -43.700048 \\
\hline PUC_7534 & Putative hybrid & $\mathrm{N}$ & Cristalia & MG/BR & L75 & -16.754727 & -42.908175 \\
\hline PUC_7535 & Putative hybrid & $\mathrm{N}$ & Cristalia & MG/BR & L75 & -16.754727 & -42.908175 \\
\hline PUC_7536 & Putative hybrid & $\mathrm{N}$ & Cristalia & MG/BR & L75 & -16.754727 & -42.908175 \\
\hline PUC_7537 & Putative hybrid & $\mathrm{N}$ & Cristalia & MG/BR & L75 & -16.754727 & -42.908175 \\
\hline PUC_7538 & Putative hybrid & $\mathrm{N}$ & Cristalia & MG/BR & L75 & -16.754727 & -42.908175 \\
\hline
\end{tabular}


Appendix 1. Continued

\begin{tabular}{llllllll}
\hline Collection no. & Species & Unit & Municipality & State/Country & Locality & Latitude & Longitude \\
\hline PUC_7539 & Putative hybrid & N & Cristalia & MG/BR & L75 & -16.754727 & -42.908175 \\
PUC_7540 & Putative hybrid & N & Grão Mogol & MG/BR & L76 & -16.557467 & -42.893887 \\
PUC_7551 & Putative hybrid & H & Ouro Branco & MG/BR & L74 & -20.517088 & -43.700048 \\
PUC_7552 & Putative hybrid & H & Ouro Branco & MG/BR & L74 & -20.517088 & -43.700048 \\
PUC_7553 & Putative hybrid & H & Ouro Branco & MG/BR & L74 & -20.517088 & -43.700048 \\
PUC_762 & Putative hybrid & H & Caeté & MG/BR & L59 & -19.880666 & -43.669804 \\
PUC_863 & Putative hybrid & H & Caeté & MG/BR & L59 & -19.880666 & -43.669804 \\
PUC_9445 & Putative hybrid & H & Nova Lima & MG/BR & L62 & -19.987594 & -43.846311 \\
PUC_962 & Putative hybrid & H & Guanhães & MG/BR & L77 & -18.771000 & -42.931888 \\
PUC_9705 & Putative hybrid & N & São João & MG/BR & L78 & -15.314933 & -42.014371 \\
& & & do Paraíso & & & & \\
\hline
\end{tabular}

